\title{
Sources and atmospheric processing of winter aerosols in Seoul, Korea: insights from real-time measurements using a high-resolution aerosol mass spectrometer
}

\author{
Hwajin Kim $^{1,2}$, Qi Zhang ${ }^{3,4}$, Gwi-Nam Bae ${ }^{1,2}$, Jin Young Kim ${ }^{1,2}$, and Seung Bok Lee ${ }^{1}$ \\ ${ }^{1}$ Center for Environment, Health and Welfare Research, Korea Institute of Science and Technology, Seoul, Korea \\ ${ }^{2}$ Department of Energy and Environmental Engineering, University of Science and Technology, Daejeon, Korea \\ ${ }^{3}$ Department of Environmental Toxicology, University of California, Davis, CA 95616, USA \\ ${ }^{4}$ Department of Environmental Science and Engineering, Fudan University, Shanghai, China \\ Correspondence to: Qi Zhang (dkwzhang@ucdavis.edu)
}

Received: 26 September 2016 - Discussion started: 11 October 2016

Revised: 29 December 2016 - Accepted: 2 January 2017 - Published: 9 February 2017

\begin{abstract}
Highly time-resolved chemical characterization of nonrefractory submicrometer particulate matter $\left(\mathrm{NR}-\mathrm{PM}_{1}\right)$ was conducted in Seoul, the capital and largest metropolis of Korea, using an Aerodyne high-resolution time-of-flight aerosol mass spectrometer (HR-ToF-AMS). The measurements were performed during winter, when elevated particulate matter (PM) pollution events are often observed. This is the first time that detailed real-time aerosol measurement results have been reported from Seoul, Korea, and they reveal valuable insights into the sources and atmospheric processes that contribute to PM pollution in this region.

The average concentration of submicron aerosol $\left(\mathrm{PM}_{1}=\mathrm{NR}_{-} \mathrm{PM}_{1}+\right.$ black carbon $\left.(\mathrm{BC})\right)$ was $27.5 \mu \mathrm{g} \mathrm{m}^{-3}$, and the total mass was dominated by organics (44\%), followed by nitrate $(24 \%)$ and sulfate $(10 \%)$. The average atomic ratios of oxygen to carbon $(\mathrm{O} / \mathrm{C})$, hydrogen to carbon $(\mathrm{H} / \mathrm{C})$, and nitrogen to carbon $(\mathrm{N} / \mathrm{C})$ of organic aerosols (OA) were $0.37,1.79$, and 0.018 , respectively, which result in an average organic mass-to-carbon (OM/OC) ratio of 1.67. The concentrations $\left(2.6-90.7 \mu \mathrm{g} \mathrm{m}^{-3}\right)$ and composition of $\mathrm{PM}_{1}$ varied dynamically during the measurement period due to the influences of different meteorological conditions, emission sources, and air mass origins. Five distinct sources of OA were identified via positive matrix factorization (PMF) analysis of the HR-ToF-AMS data: vehicle emissions represented by a hydrocarbon-like OA factor ( $\mathrm{HOA}, \mathrm{O} / \mathrm{C}=0.06$ ), cooking activities represented by a cooking $\mathrm{OA}$ factor $(\mathrm{COA}, \mathrm{O} / \mathrm{C}=0.14)$, wood combustion represented by a biomass burning OA factor
\end{abstract}

(BBOA, $\mathrm{O} / \mathrm{C}=0.34$ ), and secondary organic aerosol (SOA) represented by a semivolatile oxygenated OA factor (SV-OOA, O $/ \mathrm{C}=0.56$ ) and a low-volatility oxygenated $\mathrm{OA}$ factor ( $\mathrm{LV}-\mathrm{OOA}, \mathrm{O} / \mathrm{C}=0.68$ ). On average, primary $\mathrm{OA}(\mathrm{POA}=\mathrm{HOA}+\mathrm{COA}+\mathrm{BBOA})$ accounted for $59 \%$ the OA mass, whereas SV-OOA and LV-OOA contributed 15 and $26 \%$, respectively.

Our results indicate that air quality in Seoul during winter is influenced strongly by secondary aerosol formation, with sulfate, nitrate, ammonium, SV-OOA, and LV-OOA together accounting for $64 \%$ of the $\mathrm{PM}_{1}$ mass during this study. However, aerosol sources and composition were found to be significantly different between clean and polluted periods. During stagnant periods with low wind speed (WS) and high relative humidity $(\mathrm{RH}), \mathrm{PM}$ concentration was generally high (average $\pm 1 \sigma=43.6 \pm 12.4 \mu \mathrm{g} \mathrm{m}^{-3}$ ) with enhanced fractions of nitrate $(27 \%)$ and SV-OOA $(8 \%)$, which suggested a strong influence from local production of secondary aerosol. Low-PM loading periods $\left(12.6 \pm 7.1 \mathrm{~g} \mathrm{~m}^{-3}\right)$ tended to occur under higher-WS and lower-RH conditions and appeared to be more strongly influenced by regional air masses, as indicated by higher mass fractions of sulfate (12\%) and LV-OOA (20\%) in $\mathrm{PM}_{1}$. Overall, our results indicate that PM pollutants in urban Korea originate from complex emission sources and atmospheric processes and that their concentrations and composition are controlled by various factors, including meteorological conditions, local anthropogenic emissions, and upwind sources. 


\section{Introduction}

Ambient aerosols can reduce visibility, damage human health, and influence climate change directly by absorbing and reflecting solar radiation and indirectly by modifying cloud formation and properties (IPCC, 2013; Pope III and Dockery, 2006; Pöschl, 2005). Elevated particulate matter (PM) pollution in urban areas is known to arise due to anthropogenic emissions and stagnant meteorological conditions (Cao et al., 2012; Guo et al., 2014; Sun et al., 2014).

Seoul is one of the most populated and developed cities in Korea and is facing a severe PM pollution problem. The annual average concentration of $\mathrm{PM}_{2.5}$ in Seoul decreased from $28.5 \mu \mathrm{g} \mathrm{m}^{-3}$ in 2005 to $22.5 \mu \mathrm{g} \mathrm{m}^{-3}$ in 2012 since the enactment of the "Special Act on Seoul Metropolitan Air Quality Improvement" in 2005, which has led to emission reduction from diesel vehicles and fugitive dust emissions on roads and in open areas (Kang et al., 2016; KOSAE, 2009). However, the amount of reduction was not dramatic and the annual average $\mathrm{PM}_{2.5}$ concentration increased again in 2013 to $24.8 \mu \mathrm{g} \mathrm{m}^{-3}$. These values far exceeded the $\mathrm{PM}_{2.5}$ annual standards set by the US $\left(15 \mu \mathrm{g} \mathrm{m}^{-3}\right)$ and the WHO (World Health Organization; $10 \mathrm{\mu g} \mathrm{m}^{-3}$ ). Due to growing concerns over the adverse effects of atmospheric PM, the South Korean government established $\mathrm{PM}_{2.5}$ standards in 2015: $25 \mu \mathrm{g} \mathrm{m}^{-3}$ for annual average and $50 \mu \mathrm{g} \mathrm{m}^{-3}$ for $24 \mathrm{~h}$ average (NIER, 2014).

Mitigating air pollution in Seoul remains a great challenge because it remains unclear which emission sources and atmospheric processes are responsible for the problem (Harrison and Yin, 2000), despite numerous studies that have focused on these issues worldwide (e.g., Ervens et al., 2011; Gelencsér et al., 2007; Jimenez et al., 2009; Ng et al., 2010; Young et al., 2016; Zhang et al., 2007a). A main reason is the complexity of ambient aerosols, which have a range of chemical compositions and originate from a wide range of sources and atmospheric processes (Seinfeld and Pandis, 2006). Furthermore, several recent studies have investigated the impacts of meteorology on air pollution as well (Ding et al., 2013, 2016; Petäjä et al., 2016). For example, high PM concentration was found to happen more frequently during winter due to a combination of factors, including elevated emissions from primary sources for heating, lower boundary layer (BL) height, and stagnant meteorological conditions, which favor the accumulation of PM and secondary aerosol precursors (Hennigan et al., 2009). In addition, cold weather in winter promotes the gas-to-particle partitioning of semivolatile species such as nitrate. In addition, since Seoul is located downwind from the Asian continent, where concentrations of ambient aerosols have increased significantly in recent years (Huang et al., 2014; Liu et al., 2013; Quan et al., 2011), long-range transport of pollutants from upwind polluted areas often influences air quality in Seoul, especially during winter (Kim et al., 2014). As a result, both local and regional sources contribute to high concentrations of PM, both separately and in combination with each other (Heo et al., 2009), making air quality control more difficult. Therefore, understanding the sources and processes responsible for PM composition and concentration is critical for the public to recognize regional haze events and to enact effective PM reduction strategies for Korea as well as for the broader northern pan-Eurasian region (Liu et al., 2013). From a global point of view, studies of atmospheric PM pollution may also contribute to a better understanding of Earth system science and enactment of efficient climate policy (Kulmala et al., 2015).

Most previous aerosol studies in Korea were based on offline sampling, which involves filter collection followed by laboratory analyses. However, a main drawback of this method is low time resolution, which limits our ability to perform detailed investigations into atmospheric evolution processes. Furthermore, organic aerosol (OA) analysis conducted in Korea has so far focused on molecular level, which has led to the identification of a small portion of the OA mass (Choi et al., 2012, 2016). Aerosol mass spectrometers (AMS) have been widely used in recent years because they allow for chemical speciation, sizing, and the mass detection of nonrefractory submicrometer particulate matter (NR$\mathrm{PM}_{1}$ ), with a high time resolution (Canagaratna et al., 2007). Furthermore, using multivariate analysis methods (Zhang et al., 2011), the OA was decomposed into several sources such as hydrocarbon-like OA (HOA), biomass burning OA (BBOA), cooking-related OA (COA), coal combustion OA (CCOA), and oxygenated OA (OOA). In addition, the OOA factor has been further separated according to volatility, e.g., low-volatility fraction (LV-OOA) and a semivolatile fraction (SV-OOA) or oxidation, e.g., more oxidized (MO-OOA) and less oxidized (LO-OOA) (e.g., Lanz et al., 2007; Parworth et al., 2015; Setyan et al., 2012; Aiken et al., 2008; Huang et al., 2011; Mohr et al., 2012). These studies have identified the sources, constituents, and the evolution process of $\mathrm{PM}$, which is critical for establishing efficient control strategies and model representations (Ulbrich et al., 2009; Zhang et al., 2011).

Many AMS studies have been conducted in eastern Asia, including China, Hong Kong, and Japan, but a detailed PM characterization using AMS has not yet been reported in Seoul, Korea (Li et al., 2015 and references therein). In this study, we deployed a high-resolution time-of-flight aerosol mass spectrometer (HR-ToF-AMS), manufactured by Aerodyne Research Inc. (Billerica, MA, US), in Seoul for 6 weeks (from 5 December 2015 to 21 January 2016) to characterize winter NR-PM 1 in this urban area. We particularly focus on aerosol properties, sources, and processes in winter when the weather was generally cold and relatively dry during the day but was humid at night. Our goal was to use detailed information obtained from in situ measurements to facilitate a fundamental understanding of the formation processes and emission sources of atmospheric aerosols in Seoul, which may improve our understanding of what factors are involved and how they influences urban air quality. This information will 


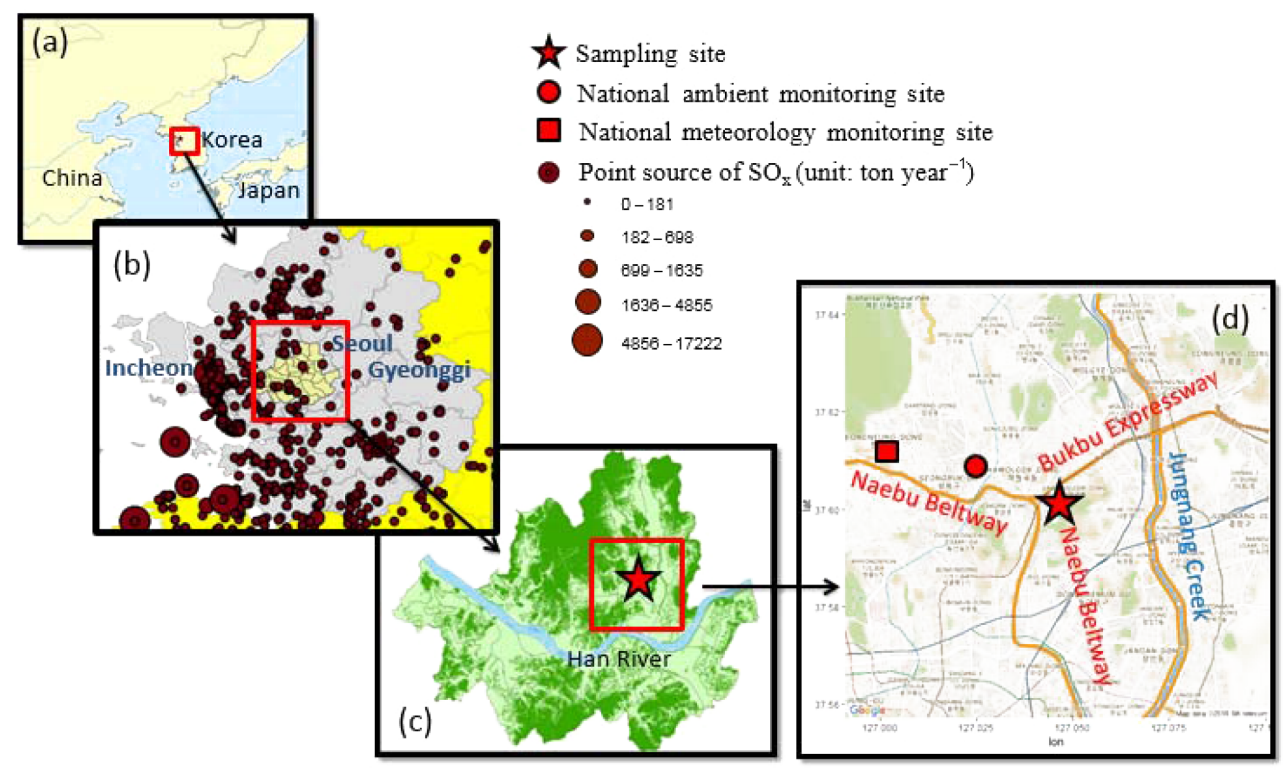

Figure 1. (a) A map of Korea showing its location between China and Japan. (b) Seoul (light yellow) surrounded by other nearby cities, including Incheon and Gyeonggi provinces (grey area) where industrial facilities are located (west); agricultural areas are sporadically located surrounding Seoul. Location of point sources of $\mathrm{SO}_{x}$ are indicated by dark red circles (size corresponds to emission rate). Agricultural areas are sporadically located to the east. (c) The location of the sampling site in Seoul, which is northeast of the center of Seoul and north of the Han River. (d) The indications of the sampling site. The Bukbu expressway is located next to the sampling site and residential and commercial areas surround the sampling site.

eventually allow for the design of better pollution abatement strategies and improved parameterizations in air quality models. Here, we report (1) the mass concentrations, size distributions, chemical composition of $\mathrm{PM}_{1}$ species, and temporal and diurnal variations in $\mathrm{PM}_{1}$ species; (2) the characteristics of and dynamic variations in OA sources and processes using PMF; and (3) the characteristics, sources, and impact factors of the $\mathrm{PM}_{1}$ composition and $\mathrm{OA}$ components on polluted and unpolluted days.

\section{Experimental methods}

\subsection{Sampling site description}

Seoul, the capital of Korea, is located west-central of the Korean Peninsula, surrounded by the Yellow Sea. Korea is generally under the influence of a prevailing northwesterly wind, bringing air masses originating from mainland China during winter (Fig. 1). In this study, real-time measurements of particle composition and size distribution were conducted at the Korea Institute of Science and Technology (KIST) located to the northeast of Seoul $\left(37.60^{\circ} \mathrm{N}, 127.05^{\circ} \mathrm{E}\right), 7 \mathrm{~km}$ from the center of Seoul. The sampling was conducted on the fifth floor of one of the KIST buildings ( $60 \mathrm{~m}$ above sea level). As shown in Fig. 1d, KIST is located $\sim 400 \mathrm{~m}$ from a busy highway and is surrounded by a residential area, forest, and a commercial area, suggesting that the air quality at the site tends to be influenced by abundant anthropogenic and pri- mary sources. There are no major industrial or wood burning sources in the vicinity of KIST. However, in the western and southwestern parts of Seoul, $\sim 35 \mathrm{~km}$ away from the measurement site (Fig. 1b), there are a number of industrial facilities that are significant anthropogenic sources for $\mathrm{SO}_{x}$ and the highest emission rate range was measured at 4856-17222 ton year $^{-1}$. There are also sporadic agricultural areas surrounding the city of Seoul (e.g., Gyeonggi Province), where open biomass burning often occurs during winter. A wide range of meteorological and air quality data were also collected from a separate supersite located $500 \mathrm{~m}$ to the northwest of the KIST.

\subsection{Measurements}

The NR-PM ${ }_{1}$ chemical components, including sulfate, nitrate, ammonium, chloride, and organics as well as their size distributions, were measured by an Aerodyne HR-ToF-AMS (DeCarlo et al., 2006) at a time resolution of $2.5 \mathrm{~min}$. The black carbon (BC) concentration was measured with a multiangle absorption photometer (MAAP; Thermo Fisher Scientific, Waltham, MA, US). Both instruments sampled downstream of a $\mathrm{PM}_{2.5}$ cyclone (URG Corp., Chapel Hill, NC, US). The number size distributions of aerosols with mobility sizes between 20.9 and $947.5 \mathrm{~nm}$ were measured by a scanning mobility particle sizer (SMPS 3080; TSI Inc., St Paul, MN, US). The hourly concentration of trace gas (e.g., CO, $\mathrm{O}_{3}, \mathrm{NO}_{2}$, and $\left.\mathrm{SO}_{2}\right)$ measured at the Gireum site $\left(37.61^{\circ} \mathrm{N}\right.$, 
$\left.127.03^{\circ} \mathrm{E}\right)$ was acquired from the Korea Environment Corporation (K eco) (http://www.airkorea.or.kr). Meteorological measurement data such as ambient temperature, relative humidity (RH), wind speed, and wind direction were obtained from the nearby Jungreung site $\left(37.61^{\circ} \mathrm{N}, 127.00^{\circ} \mathrm{E}\right)$, which is maintained by the Korea Meteorological Administration (http://www.kma.go.kr). The data reported in this paper are in local time, which is Korea Standard Time (KST) and is $9 \mathrm{~h}$ earlier than Universal Coordinated Time (UTC).

In this study, the HR-ToF-AMS was operated in the standard configuration and obtained mass spectra (MS) and efficient particle time of flight (ePToF) data. Furthermore, the HR-ToF-AMS was operated under the "V" and "W" modes, where high sensitivity but low mass resolution was achieved in $\mathrm{V}$ mode, and low sensitivity but high mass resolution was achieved in $\mathrm{W}$ mode. Ionization efficiency (IE) and particle sizing calibrations were performed following standard protocols (Canagaratna et al., 2007) before, during, and after the measurement period.

\subsection{AMS data analysis}

\subsubsection{Basic HR-ToF-AMS data analysis}

HR-ToF-AMS data were processed and analyzed using the standard toolkit (SeQUential Igor data RetRiEval, SQUIRREL, ver. 1.57I, and PIKA, ver. 1.16I; available for download at http://cires.colorado.edu/jimenez-group/ ToFAMSResources/ToFSoftware/index.html) within Igor Pro (WaveMetrics, Lake Oswego, OR, US). Details on the data processing procedures have been described in previous studies (Aiken et al., 2008, 2009; Allan et al., 2004). Briefly, the standard fragmentation table described by Allan et al. (2004) was used, with some small modifications to process the raw MS. The modifications were based on data from four filtered air measurements. This allowed measurements of the background from the gas-phase signal, which needed to be removed from the particle-phase measurement. Adjustments were made to the measured $\mathrm{CO}_{2}^{+}(\mathrm{m} / \mathrm{z}=44)$ signal to remove the contributions from gas-phase $\mathrm{CO}_{2}$ as well as the ${ }^{16} \mathrm{O}^{+}$-to- ${ }^{14} \mathrm{~N}^{+}$ratio for air signals at $m / z=29$ based on measurements of particle-free ambient air. Relative ionization efficiencies (RIE) of 1.1, 1.075, and 3.875 were used for nitrate, sulfate, and ammonium, respectively, based on values determined from calibrations using pure $\mathrm{NH}_{4} \mathrm{NO}_{3}$ and $\left(\mathrm{NH}_{4}\right)_{2} \mathrm{SO}_{4}$ aerosols. A composition-dependent collection efficiency (CE) was applied to the data based on an algorithm by Middlebrook et al. (2012). Nitrate was observed to be an important component of NR-PM 1 during this study $(24 \%)$, although the campaign average $( \pm 1 \sigma)$ $\mathrm{CE}$ was $0.5 \pm 0.02$. Furthermore, the total concentrations of particle-bound polycyclic aromatic hydrocarbons (PAHs) were estimated using the method described in Dzepina et al. (2007). However, instead of apportioning the unit mass resolution (UMR) spectra, PAH-related ions were deter- mined via fitting the high-resolution mass spectra (W-mode) (Xu et al., 2014). In addition, a RIE of 1.35 with respect to nitrate was applied to calculate mass concentrations of PAHs from AMS data (Dzepina et al., 2007).

The quantification of NR-PM $\mathrm{N}_{1}$ species was validated through comparisons between the total $\mathrm{PM}_{1}$ mass $\left(\mathrm{PM}_{1}=\mathrm{NR}-\mathrm{PM}_{1}+\mathrm{BC}\right)$ and the apparent particle volume measured by the SMPS (Figs. 2e and S1a in the Supplement). As shown in Fig. S1a, the SMPS-measured particle volume correlated strongly with the AMS-measured total mass $\left(R^{2}=0.9\right)$. From this strong correlation, the inter-comparison of AMS mass versus SMPS volume yielded a slope of 1.22, which was lower than the average particle density of $1.46 \mathrm{~g} \mathrm{~m}^{-3}$ estimated using the measured chemical composition in this study (Zhang et al., 2005b) (Figs. 3c, S1b). Note that the average organic aerosol density was estimated to be $1.12 \mathrm{~g} \mathrm{~m}^{-3}$ based on elemental ratios (Kuwata et al., 2012). The evolution pattern of the AMS total mass-based size distribution also compared well with the volume-based size distribution from SMPS measurements throughout the day (Fig. S1c, d). The detection limits of the main chemical components in AMS are listed in Table 1 and are typically far lower than the observed concentrations. All the reported mass concentrations from AMS in this study are based on ambient conditions.

The elemental ratios between oxygen, carbon, hydrogen, nitrogen, and sulfur, as well as the organic mass-to-carbon ratio (OM / OC) of OA, were determined from an analysis of the W-mode high-resolution mass spectra (HRMS) data, following the method recently reported by Canagaratna et al. (2015). The elemental ratios calculated using the Aikenambient method (Aiken et al., 2008) are detailed in Table S1 along with the ratios calculated using the Canagaratna method for comparison. Unless otherwise indicated, the $\mathrm{O} / \mathrm{C}, \mathrm{H} / \mathrm{C}$, and $\mathrm{OM} / \mathrm{OC}$ ratios stated in this paper from other studies have been calculated using the updated elemental analysis method (Canagaratna et al., 2015). Note that there could be biases in the $\mathrm{S} / \mathrm{C}$ ratios since no correction factor is available.

\subsubsection{Positive matrix factorization (PMF) analysis}

The HRMS of organic aerosol were analyzed using PMF. The analysis was performed using the PMF2 algorithm in robust mode (Paatero and Tapper, 1994), with the PMF Evaluation Toolkit (PET ver 2.05) (Ulbrich et al., 2009), which was downloaded from http://cires1.colorado.edu/ jimenez-group/wiki/index.php/PMF-AMS_Analysis_

Guide\#PMF_Evaluation_Tool_Software. The data and error matrices were prepared according to the protocol described by Ulbrich et al. (2009) and outlined in Table 1 of Zhang et al. (2011). In brief, a minimum error value was applied to the error matrix and each ion was assessed and treated according to its signal-to-noise ratio (SNR). Ions with an average SNR of less than 0.2 were removed, and those with 


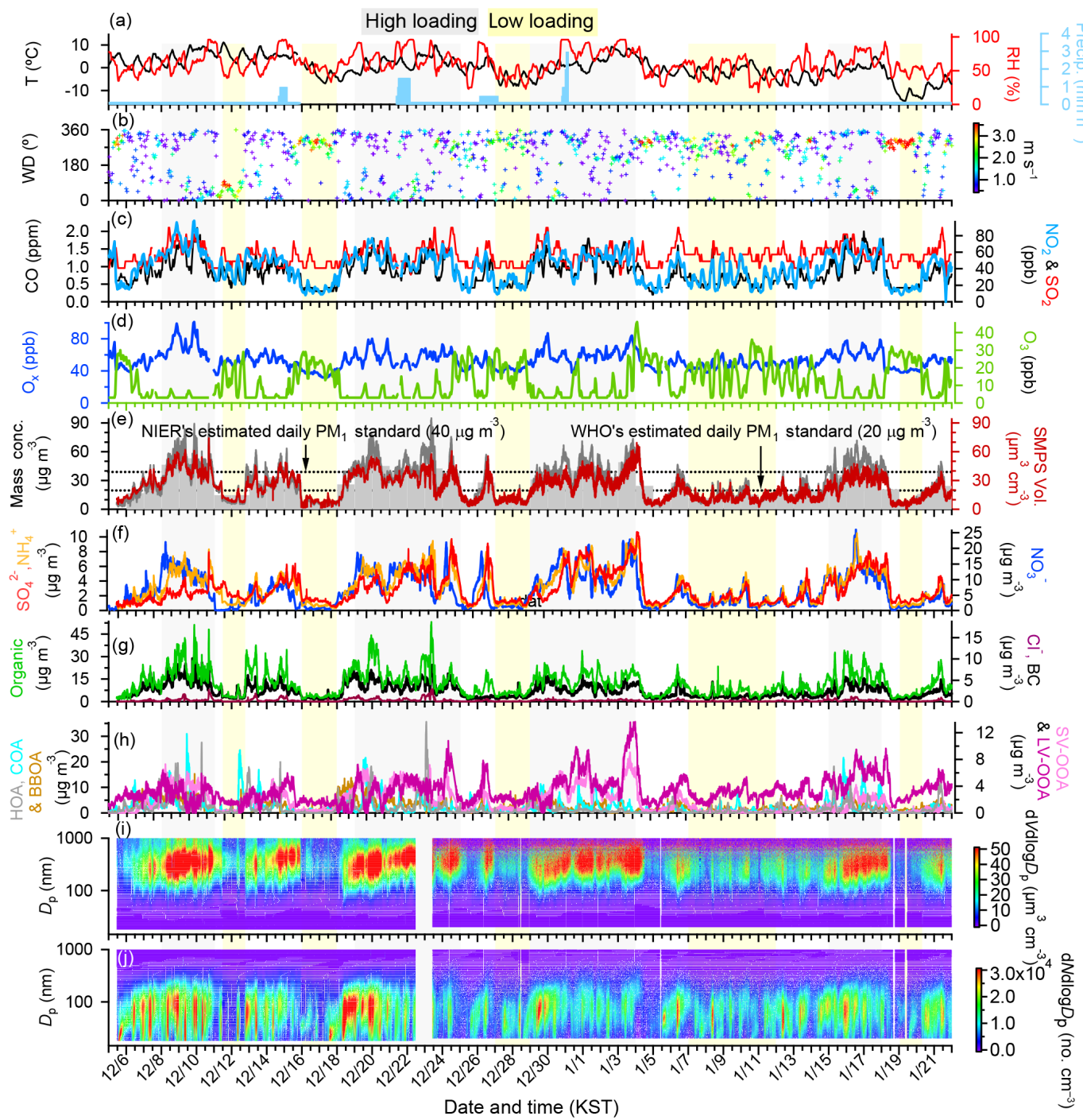

Figure 2. Overview of the temporal variations in submicron aerosols at the KIST in Seoul from 5 December 2015 to 21 January 2016. (a) Time series of ambient air temperature $(T)$, relative humidity (RH), solar radiation (SR), and precipitation (Precip.); (b) time series of wind direction (WD), with colors showing different wind speeds (WS); (c) time series of $\mathrm{CO}, \mathrm{SO}_{2}$, and $\mathrm{NO}_{2} ;(\mathbf{d})$ time series of $\mathrm{O}_{x}\left(\mathrm{NO}_{2}+\mathrm{O}_{3}\right)$ and $\mathrm{O}_{3}$; (e) time series of total particulate matter $\left(\mathrm{PM}_{1}\right)$, and scanning mobility particle sizer (SMPS) volume concentrations. Also shown are the $24 \mathrm{~h}$ averaged $\mathrm{PM}_{1}+\mathrm{BC}$ with bars. Estimated NIER and WHO daily $\mathrm{PM}_{1}$ standards $\left(40\right.$ and $20 \mu \mathrm{g} \mathrm{m}^{-3}$, respectively) are also shown as dashed lines for the comparisons; (f) time series of the organic aerosols (Org.), nitrate $\left(\mathrm{NO}_{3}^{-}\right)$, sulfate $\left(\mathrm{SO}_{4}^{2-}\right)$, ammonium $\left(\mathrm{NH}_{4}^{+}\right)$, chloride $\left(\mathrm{Cl}^{-}\right)$, and $\mathrm{BC} ;(\mathrm{g})$ time series of the total organic aerosol $(\mathrm{OA})$ of the five factors derived from the positive matrix factorization (PMF) analysis (see Sect. 3.3). (h,i) Particle volume and number size distributions by SMPS. Shaded regions indicate the persistent ( $>2$ days) high-loading (gray) and low-loading (yellow) periods when daily average conc. $>30 \mu \mathrm{g} \mathrm{m}^{-3}$ and $<14 \mu \mathrm{g} \mathrm{m}^{-3}$, respectively.

a SNR between 0.2 and 2 were downweighted by increasing their errors by a factor of 2 . Furthermore, ions related to $m / z 44$ (i.e., $\mathrm{CO}_{2}^{+}, \mathrm{CO}^{+}, \mathrm{H}_{2} \mathrm{O}^{+}, \mathrm{HO}^{+}$, and $\mathrm{O}^{+}$) were also downweighted to avoid overestimating the importance of $\mathrm{CO}_{2}^{+}$. Isotopes were removed from the matrices because their signals were scaled to their parent ions rather than being measured directly. After these treatments, the resulting matrix consisted of 286 ions between $m / z$ 's 12 and 120 .
PMF was applied to the data and the number of factors ( $p$, $1-9$ ) in the solution was explored. Although the PMF algorithm was able to provide a number of mathematically sound solutions, in order to obtain physically meaningful results, several criteria were used to evaluate and select the appropriate number of factors from the model. The recommendations outlined in Zhang et al. (2011), including an investigation of the key diagnostic plots, mass spectral signatures, diurnal 

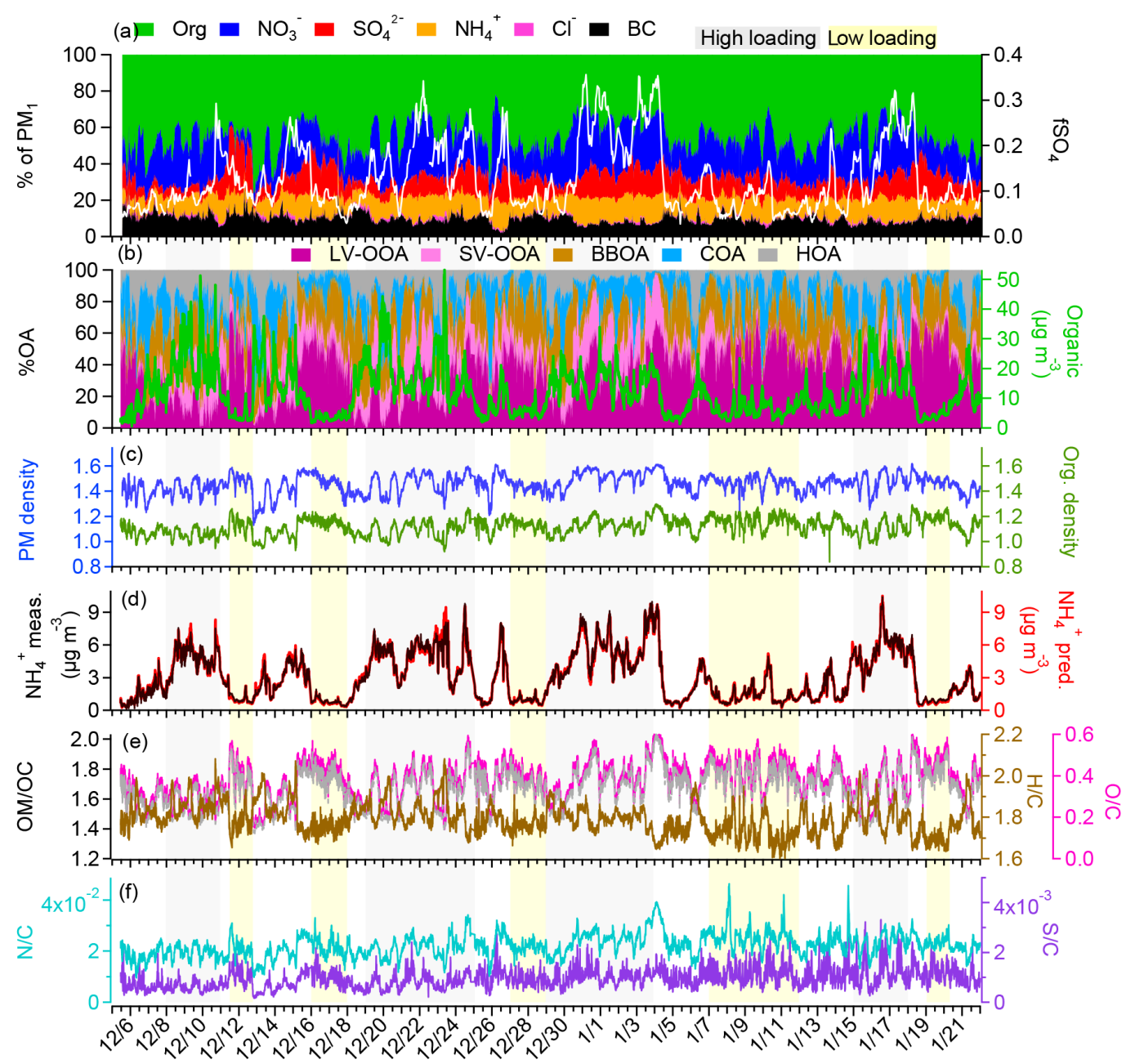

Date \& time (KST)

Figure 3. Overview of the chemical composition of submicron aerosols at the KIST in Seoul from 5 December 2015 to 21 January 2016. (a) Time series of the mass fractional contribution of organic aerosols (Org.), nitrate $\left(\mathrm{NO}_{3}^{-}\right)$, sulfate $\left(\mathrm{SO}_{4}^{2-}\right)$, ammonium $\left(\mathrm{NH}_{4}^{+}\right)$, chloride $\left(\mathrm{Cl}^{-}\right)$, and $\mathrm{BC}$ to total $\mathrm{PM}_{1}$. Also shown is the time series of $f \mathrm{SO}_{4}$ (ratio of $\mathrm{SO}_{4}^{2-} /\left(\mathrm{SO}_{2}+\mathrm{SO}_{4}^{2-}\right)$ ); (b) time series of the mass fractional contribution to total organic aerosol (OA) of the five factors derived from the positive matrix factorization (PMF) analysis (see Sect. 3.3), and the time series of the organic aerosols; (c) time series of the organic density estimate using the method reported in Kuwata et al. (2012), with bulk aerosol density using the organic density estimated in this figure; (d) time series of the measured and predicted $\mathrm{NH}_{4}^{+}$concentrations; $(\mathbf{e}, \mathbf{f})$ organic matter-to-organic carbon $(\mathrm{OM} / \mathrm{OC})$, oxygen-to-carbon $(\mathrm{O} / \mathrm{C})$, hydrogen-to-carbon $(\mathrm{H} / \mathrm{C})$, nitrogen-to-carbon $(\mathrm{N} / \mathrm{C})$, and sulfur-to-carbon $(\mathrm{S} / \mathrm{C}$ ) ratios of $\mathrm{OA}$, where the $\mathrm{O} / \mathrm{C}, \mathrm{H} / \mathrm{C}$, and $\mathrm{OM} / \mathrm{OC}$ elemental ratios were determined using the updated method (Canagaratna et al., 2015).

profiles, and correlations with external tracers, were followed to assess the results and determine the number of factors.

The rotational ambiguity of each of the solution sets was explored by varying the $f$ Peak parameter from -1 to 1 , with increments of 0.1 . The five-factor solution with $f$ Peak $=0$ $\left(Q / Q_{\exp }=2.56\right)$ was selected for further analyses because it satisfied the criteria above, including a good separation of the temporal and mass spectral variations in the five factors. A summary of the key diagnostics is presented in Fig. S2. The five-factor solution was found to be very stable since the mass fraction of each of the factors remained relatively constant between $f$ Peaks -0.4 and +0.2 (Fig. S2c). Figure $\mathrm{S} 3$ shows the mass spectra and the time series of the four- and six-factor solutions, where factors 1 and 2 in the four-factor solution set could be identified as LV-OOA and SV-OOA, respectively, based on the $\mathrm{O} / \mathrm{C}$ ratio. However, both were highly oxidized, with a higher fraction of $\mathrm{m} / z 44$ than $m / z$ 43. Moreover, all factors in this solution set showed the signature of biomass burning OA (BBOA) at $m / z 60$ and $m / z$ 73, indicating that more factors may be needed to resolve the mixed factors. In contrast, the temporal variations from the six-factor solution were similar to those from the 
Table 1. Average ( \pm 1 standard deviation), minimum, and maximum concentrations of the $\mathrm{PM}_{1}$ species and the total $\mathrm{PM}_{1} \mathrm{mass}_{\mathrm{s}}$ over the whole campaign, and the average contribution of each of the $\mathrm{PM}_{1}$ species to the total $\mathrm{PM}_{1}$ mass.

\begin{tabular}{|c|c|c|c|c|c|}
\hline & $\begin{array}{r}\text { Average conc. } \pm 1 \\
\text { standard deviation } \\
\left(\mu \mathrm{g} \mathrm{m}^{-3}\right)\end{array}$ & $\begin{array}{l}\text { Minimum conc. } \\
\qquad\left(\mu \mathrm{g} \mathrm{m}^{-3}\right)\end{array}$ & $\begin{array}{r}\text { Maximum conc. } \\
\qquad\left(\mu \mathrm{g} \mathrm{m}^{-3}\right)\end{array}$ & $\begin{array}{r}\text { Fraction of total } \mathrm{PM}_{1} \\
\qquad(\%)\end{array}$ & $\begin{array}{r}\text { Detection limit } \\
(3 \mathrm{~min} \text { and } 6 \mathrm{~min}) \\
\left(\mu \mathrm{g} \mathrm{m}^{-3}\right)\end{array}$ \\
\hline Organics & $12.1 \pm 8.03$ & 1.32 & 53.1 & 44 & $0.03 / 0.02$ \\
\hline Nitrate & $6.55 \pm 5.12$ & 0.18 & 26.0 & 24 & $0.01 / 0.01$ \\
\hline Sulfate & $2.87 \pm 2.00$ & 0.38 & 10.7 & 10 & $0.01 / 0.01$ \\
\hline Ammonium & $3.11 \pm 2.20$ & 0.21 & 10.5 & 12 & $0.02 / 0.01$ \\
\hline Chloride & $0.26 \pm 0.32$ & 0 & 2.91 & 1 & $0.01 / 0.01$ \\
\hline Black carbon & $2.54 \pm 1.66$ & 0 & 10.1 & 9 & $0.1 / 0.05$ \\
\hline Total $\mathrm{PM}_{1}$ & $27.5 \pm 17.2$ & 1.32 & 90.7 & - & $0.04 / 0.03$ \\
\hline
\end{tabular}

five-factor solution set but showed indications of factor splitting. For example, two very similar BBOA-like factors (factors 3 and 4) were identified in the six-factor solution, where the main difference was that factor 4 had a higher $\mathrm{N} / \mathrm{C}$ ratio than factor 3 did. Although different types of BBOA sources are possible, we did not have external evidence to validate the separation. Furthermore, given the fact that having only one BBOA factor (i.e., the five-factor solution set) did not influence the separation of the other factors, it was not necessary to select a higher number of factors. Consequently, the fivefactor solution, which resolved HOA, COA, BBOA, and two types of OOA, was chosen since it appears to best represent OA sources and processes in Seoul during winter.

\subsection{Back-trajectory and bivariate conditional probability function analysis}

In this study, $96 \mathrm{~h}$ back trajectories were calculated every hour using version 4.9 of the Hybrid Single-Particle Lagrangian Integrated Trajectory (HYSPLIT) model (Draxler, $2012,1997)$ for the sampling periods from 5 December 2015 to 21 January 2016. The trajectories were released at half of the mixing height at the KIST (latitude: $37.60^{\circ} \mathrm{N}$, longitude: $127.05^{\circ} \mathrm{E}$ ) and the average arriving height for the back trajectories for this study was approximately $191 \mathrm{~m}$. To identify the pollutant characteristics in different predominant transport patterns, cluster analysis was performed on the trajectories using the software HYSPLIT4 and four clustered trajectories were identified according to their similarity in a spatial distribution. Individual back trajectories in each cluster are shown in Fig. S12.

In addition, conditional probability function (CPF) (Kim et al., 2003) was performed to estimate the local sources and their impacts on $\mathrm{PM}_{1}$ composition and individual organic aerosol sources from PMF analysis, using wind directions coupled with the concentration time series of each species. The CPF plots represent the probability that a specific compound or source is located in a certain wind direction, helping to find the local point source. The directional origin of re- gionally transported sources may not be consistent with the local surface wind data used for the CPF plots due to the topography of the region (Heo et al., 2009).

\section{Results and discussion}

\subsection{Overall characteristics}

\subsubsection{Temporal variations in $\mathrm{PM}_{1}$ composition and chemical properties}

The overall characteristics and temporal variations in winter $\mathrm{PM}_{1}$ in Seoul, including mass and volume concentrations and size distributions, are shown in Fig. 2, along with the time series of gaseous pollutants, e.g., $\mathrm{CO}, \mathrm{SO}_{2}$, and $\mathrm{O}_{x}\left(\mathrm{O}_{x}=\mathrm{O}_{3}+\mathrm{NO}_{2}\right)$ and meteorological conditions $(\mathrm{RH}$, temperature, wind direction, wind speed). From 5 December 2015 to 21 January 2016, the average concentration of $\mathrm{PM}_{1}$ (=NR-PM $+\mathrm{BC}$ ) was $27.5 \mu \mathrm{g} \mathrm{m}^{-3}$, ranging from 2.6 to $90 \mu \mathrm{g} \mathrm{m}^{-3}$. Assuming that $\mathrm{PM}_{1}$ represents approximately $80 \%$ of $\mathrm{PM}_{2.5}$ mass (Lim et al., 2012), we found that $29 \%$ of the measurement days (i.e., 14 days) violated the National Institute of Environmental Research (NIER)'s daily $\mathrm{PM}_{2.5}$ standard $\left(50 \mu \mathrm{g} \mathrm{m}^{-3}\right)$ and $58 \%$ of the days (28 days) violated the WHO's daily standard $\left(25 \mu \mathrm{g} \mathrm{m}^{-3}\right)$. Although severe haze with high $\mathrm{PM}_{1}$ concentration close to $90 \mu \mathrm{g} \mathrm{m}^{-3}$ was observed several times, the average mass concentration of $\mathrm{PM}_{1}\left(27.5 \mu \mathrm{g} \mathrm{m}^{-3}\right)$ was still moderate because of the frequent occurrence of clean periods in winter. The average concentration of $\mathrm{PM}_{1}$ measured in Korea during this study was similar to or slightly lower than that measured in winter in several urban areas in China, including Shanghai (Huang et al., 2012), Shenzhen (He et al., 2011), Lanzhou (Xu et al., 2016), and Hong Kong (Li et al., 2015), but it was much lower than in Beijing where the winter mass concentrations of $\mathrm{PM}_{1}$ were found to be 7-10 times higher than in Seoul (Sun et al., 2014).

The large variations in $\mathrm{PM}_{1}$ mass concentrations (2.6$90 \mu \mathrm{g} \mathrm{m}^{-3}$; Fig. 2e) and other pollutants (Fig. 2c), such as CO 
(0.3-2.3 ppm), $\mathrm{O}_{3}(3-46 \mathrm{ppb})$, and $\mathrm{NO}_{2}$ (8-98 ppb), reflected that air quality in Seoul is influenced by dynamic changes in emission sources, atmospheric processes, and meteorological conditions. In addition, new particle events were observed during this study and they showed characteristics of a sharp increase in ultrafine particle number concentration and subsequent growth of these particles in size (Fig. 2j). This is the first finding of its kind in an urban area of Korea, although frequent $(\sim 7.4 \%$ of the measurement days) observations of new particle formation and growth events were reported from the 3-year continuous measurements using SMPS at the Gosan station $\left(33.17^{\circ} \mathrm{N}, 126.10^{\circ} \mathrm{E}\right)$, which is in a pristine rural area but is downwind of the Asian continent and faces the Yellow Sea (Kim et al., 2013).

Based on the variations in $\mathrm{PM}_{1}$ concentrations and meteorological conditions (Fig. 2), we divided the whole study into two typical periods: (1) high-loading period (daily $\mathrm{PM}_{1}>30 \mu \mathrm{g} \mathrm{m}^{-3}$ ) and (2) low-loading period (daily $\mathrm{PM}_{1}<$ $14 \mu \mathrm{g} \mathrm{m}^{-3}$ ). Of the $\mathrm{PM}_{1}$ concentrations estimated based on the NIER and WHO daily and yearly PM $_{2.5}$ standards, 30 and $14 \mu \mathrm{g} \mathrm{m}^{-3}$ correspond to the middle values, respectively. As shown in Figs. 2 and 3, high and low-loading periods usually alternated during winter in Seoul. Comparisons between the high and low-loading periods can indicate how different sources and atmospheric processes influence air quality in this region. Details on the periodic variations in air quality in Seoul are discussed in Sect. 3.4.

On average, OA was the largest component of the $\mathrm{PM}_{1}$, accounting for $44 \%$ of the total mass, followed by nitrate $(24 \%)$, sulfate $(10 \%)$, ammonium $(12 \%)$, BC $(9 \%)$ and chloride (1\%) (Figs. 3a, 4a and Table 1). POA (primary organic aerosol, $=\mathrm{HOA}+\mathrm{COA}+\mathrm{BBOA})$ and SOA $(=\mathrm{SV}$ OOA + LV-OOA) accounted for 59 and $41 \%$, respectively, of OA mass (Sect. 3.3). Consequently, $\sim 36 \%$ of $\mathrm{PM}_{1}$ consisted of primary materials $(\mathrm{POA}+\mathrm{BC})$, with the remainder $(64 \%)$ being secondary species $\left(\mathrm{NO}_{3}^{-}+\mathrm{SO}_{4}^{2-}+\mathrm{NH}_{4}^{+}+\right.$ $\mathrm{SOA})$. This indicates that the aerosol pollution problem in Seoul during winter was more strongly influenced by secondary aerosol formation processes. Details on the sources and processes that led to severely bad air quality are discussed in Sect. 3.4.

The molar-equivalent ratios of total inorganic anions to cation for NR-PM $\left(=\left(\mathrm{SO}_{4}^{2-} / 48+\mathrm{NO}_{3}^{-} / 62+\right.\right.$ $\left.\left.\mathrm{Cl}^{-} / 35.5\right) /\left(\mathrm{NH}_{4}^{+} / 18\right)\right)$ were close to 1 ; thus, submicron aerosols were mostly neutralized in the forms of ammonium salts such as $\mathrm{NH}_{4} \mathrm{NO}_{3},\left(\mathrm{NH}_{4}\right)_{2} \mathrm{SO}_{4}$, and $\mathrm{NH}_{4} \mathrm{Cl}$ (Zhang et al., 2007b) (Figs. 3d and 4b). Possible sources of ammonium in Seoul include on-road vehicle emissions, the use of neutralizers in industry, and agricultural emissions on the outskirts of Seoul. Note that particles appeared to have "excess" $\mathrm{NH}_{4}^{+}$at high organic aerosol loadings (Fig. 4b), probably due to the presence of carboxylate ions such as formate, acetate, and oxalate, which were not counted in the calculation of ion balance (Ge et al., 2012b). Further investigations into this issue might be necessary in the future.

\subsubsection{Diurnal patterns of $\mathrm{PM}_{1}$ composition}

Diurnal patterns can provide insights into aerosol sources and formation processes. In this study, the daily variations in concentrations of aerosol species show distinctively different patterns, indicating that the sources and formation processes of PM pollutants in Seoul were diverse and complex. First, secondary inorganic species, such as sulfate, nitrate, and ammonium, all displayed different diurnal profiles. In the case of nitrate (Fig. 5c), the daily variations started to increase at $\sim 07: 00$, peaked at midday (10:00-12:00), and then slowly decreased until 17:00. Previous studies (Brown et al., 2006; Lurmann et al., 2006; Sun et al., 2012; Young et al., 2016; Xu et al., 2014) attributed this type of daytime peak shortly after sunrise to the mixing down of secondary aerosols formed at night in a residual layer aloft. Later, the photochemical formation of nitrate from $\mathrm{NO}_{x}$, emitted from rush hour traffic, contributed to an increase in nitrate concentration during the day, a feature of regionally generated secondary inorganic species. The decreasing trend in the afternoon is likely due to the evaporative loss of semivolatile species at higher air temperatures as well as the dilution effects due to the enhanced BL height in the afternoon. A significant amount of nitrate can also be formed through nighttime chemistry, as indicated by the high fractional contribution at night (Fig. 5f). Given that somewhat high concentrations of $\mathrm{O}_{3}(\sim 12.0 \mathrm{ppb})$ and $\mathrm{NO}_{2}(\sim 41.7 \mathrm{ppb})$ were observed at night (18:00-6:00) (Fig. S10), nitrate formation from $\mathrm{N}_{2} \mathrm{O}_{5}$ hydrolysis possibly occurred.

Unlike nitrate, sulfate concentration was elevated at night, showing a trend that started to increase from late afternoon ( 16:00), peaked at around 10:00 on the following day, and then gradually decreased afterwards to reach a minimum value at 16:00 (Figs. 5b, 6b). The overnight increase starting in the late afternoon appeared to be associated with enhanced gas-to-particle partitioning of $\mathrm{SO}_{2}$ and aqueous-phase processing facilitated by the relatively low temperature and high $\mathrm{RH}$ at night (Fig. 6). Indeed, $f \mathrm{SO}_{4}(=$ the ratio in sulfate $\left(\mathrm{SO}_{4}^{2-}\right)$ to $\mathrm{SO}_{x}\left(\mathrm{SO}_{4}^{2-}+\mathrm{SO}_{2}\right)$ based on sulfur contents; Kaneyasu et al., 1995) increased at night and showed relatively good correlation with $\mathrm{RH}\left(R^{2}=0.59\right.$, Fig. 6a). However, $f \mathrm{SO}_{4}$ started to decrease at $\sim 6: 00$ (Fig. $6 \mathrm{c}$ ) but sulfate concentration continued to increase until 10:00 (Fig. 6b). This increase in sulfate concentration appeared to be due to a similar reason as that of nitrate - mixing with the higher concentration of sulfate in the upper residual layer formed at night. The residual layer was also enriched with $\mathrm{SO}_{2}$ (Fig. 6b), for which nighttime transport of air mass from industrial facilities located on the western (Fig. S11) and southwestern outskirts of Seoul (Fig. 1b) might be responsible. However, the bivariate polar plots (Fig. 7) indicate that high $\mathrm{SO}_{2}$ concentration tended to occur under high-speed 

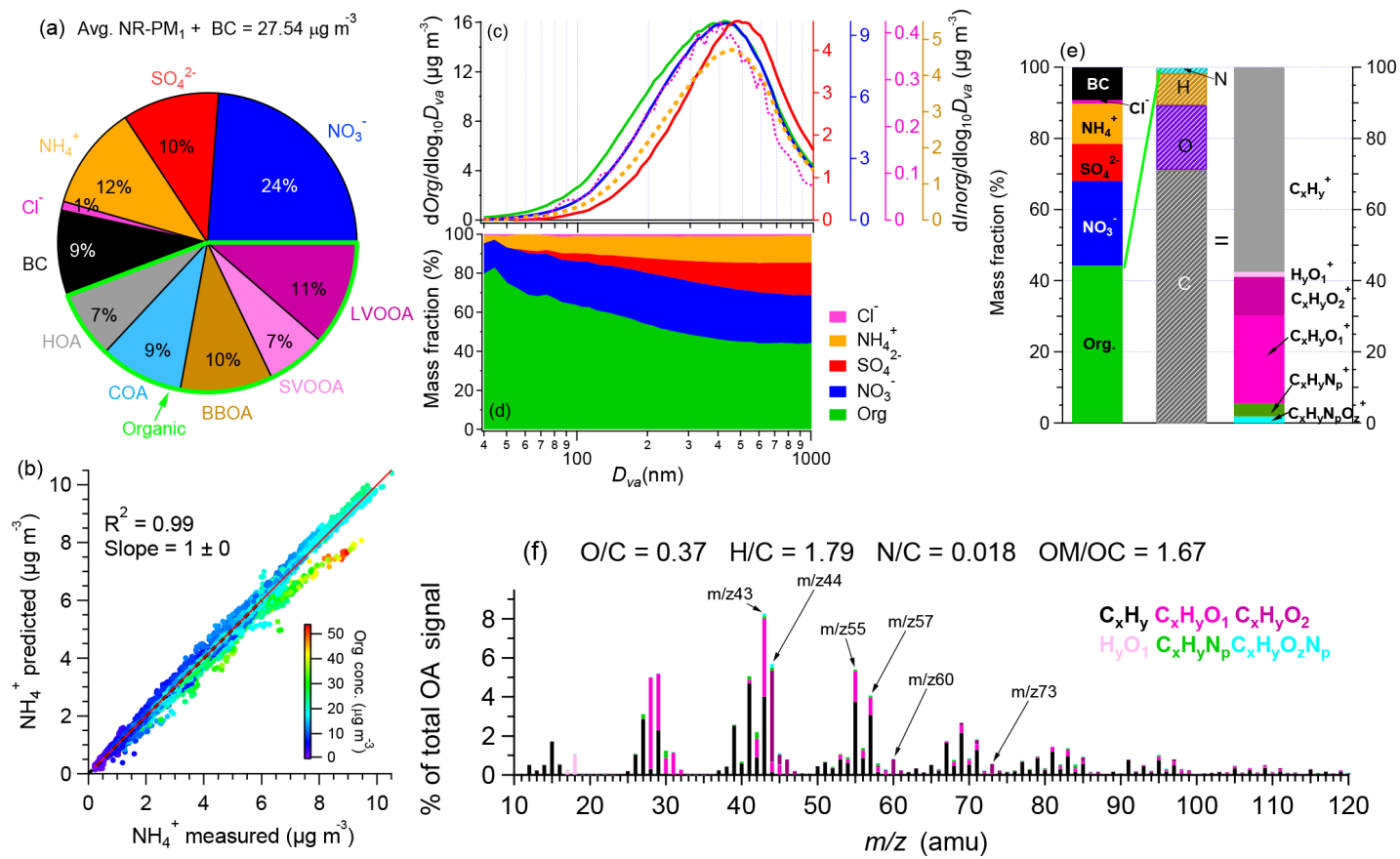

Figure 4. (a) Average compositional pie chart of $\mathrm{PM}_{1}$ species (nonrefractory $\mathrm{PM}_{1}$ plus black carbon (BC)) and each of the $\mathrm{OA}$ factors over the whole campaign. The green outline indicates the fraction of total $\mathrm{OA}$ and (b) shows a scatterplot that compares predicted $\mathrm{NH}_{4}^{+}$vs. measured $\mathrm{NH}_{4}^{+}$concentrations. The predicted values were calculated assuming full neutralization of the anions (e.g., sulfate, nitrate, and

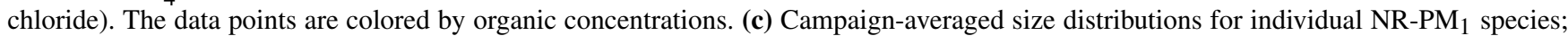
(d) averaged mass fractional contributions of each NR-PM 1 species to the total NR-PM 1 mass as a function of size. (e) Overview of the average $\mathrm{PM}_{1}$ and $\mathrm{OA}$ compositions in Seoul during winter; (f) average high-resolution mass spectrum of OA colored by the different ion families. The average elemental ratios for the OA fraction are described.

wind from the south and southeast, which shifted relative to the locations of the $\mathrm{SO}_{2}$ point sources (Fig. 1b). The reason might be geographical since the position (north) of the Bukhan Mountain blocks the wind and promotes the circulation of air masses. Similar trends were observed in a previous study (Heo et al., 2009).

The decrease in both sulfate and $\mathrm{SO}_{2}$ concentrations between 10:00 and 17:00 (Fig. 6b) could be due to the dilution effect from rising BL height. Since $f \mathrm{SO}_{4}$ showed only minor increases between 12:00 and 17:00 when RH was low (Fig. 6c), gas-phase photochemical production of sulfate during the day was unlikely to be an important process. This observation, together with the nighttime increase of sulfate associated with high $\mathrm{RH}$, suggests that aqueous phase processing is an important driver for sulfate formation in Seoul in winter. This conclusion is consistent with previous studies that found that aqueous phase reactions were an important pathway for sulfate formation in the atmosphere under humid conditions (Ervens et al., 2011; Ge et al., 2012b).

In this study, as mentioned in the earlier section, nitrate, sulfate, and chloride in $\mathrm{PM}_{1}$ appeared to be fully neutralized by ammonium, indicating that the inorganic species were mainly present in the forms of $\mathrm{NH}_{4} \mathrm{NO}_{3},\left(\mathrm{NH}_{4}\right)_{2} \mathrm{SO}_{4}$, and $\mathrm{NH}_{4} \mathrm{Cl}$. Since nitrate was more abundant compared to sul- fate and chloride (Fig. 4a), the ammonium diurnal pattern was similar to that of nitrate. However, a gradual increase in ammonium was observed at night, likely due to the enhancement of the sulfate concentration. Chloride accounted for a small fraction of the $\mathrm{PM}_{1}$ mass and displayed a morning rush hour peak, suggesting that the source of chloride is probably local, such as vehicle emissions. Indeed, the polar plot of chloride in Fig. 7 does show the feature of local source since high concentration occurred mostly at slow wind speed. Furthermore, chloride showed a similar diurnal pattern as HOA (Sect. 3.3, Fig. 10) and good correlation with HOA $(r=0.8$, Table 2).

In contrast to ammonium and nitrate, OA concentration tended to remain high overnight and started to increase in the morning, with a maximum usually occurring at 8:00 (Fig. 5a). This morning increase was likely the outcome of a shallow BL coupled with enhanced primary emissions from rush-hour traffic. Further discussions on this are given in Sect. 3.3.

\subsection{Size distributions of the main components of $\mathbf{P M}_{1}$}

The average mass-based size distributions of AMS species in terms of vacuum aerodynamic diameter $\left(D_{\text {va }}\right.$; DeCarlo 
Table 2. Correlation coefficient (Pearson's $r$ ) for the linear regressions between organic aerosol (OA) factors, including the sum of primary factors (primary OA $(\mathrm{POA})=$ hydrocarbon-like OA $(\mathrm{HOA})+$ cooking OA $(\mathrm{COA})+$ biomass burning OA $(\mathrm{BBOA})$ ), as well as the sum of the oxidized factors (oxidized OA $(\mathrm{OOA})=$ semivolatile OOA (SV-OOA) + low-volatile (LV-OOA)), and various particle- and gas-phase species and ions.

\begin{tabular}{|c|c|c|c|c|c|c|c|}
\hline$r$ & $\mathrm{HOA}$ & $\mathrm{COA}$ & BBOA & $\begin{array}{c}\mathrm{POA} \\
(\mathrm{HOA}+\mathrm{COA} \\
+\mathrm{BBOA})\end{array}$ & SV-OOA & LV-OOA & $\begin{array}{c}\text { OOA } \\
(\mathrm{SV}-\mathrm{OOA} \\
+\mathrm{LV}-\mathrm{OOA})\end{array}$ \\
\hline Nitrate & 0.32 & 0.30 & 0.41 & 0.43 & 0.87 & 0.63 & 0.87 \\
\hline Sulfate & 0.25 & 0.17 & 0.09 & 0.23 & 0.71 & 0.80 & 0.88 \\
\hline Ammonium & 0.41 & 0.30 & 0.37 & 0.45 & 0.87 & 0.69 & 0.90 \\
\hline Chloride & 0.80 & 0.30 & 0.50 & 0.68 & 0.50 & 0.13 & 0.36 \\
\hline K (AMS) & 0.59 & 0.60 & 0.63 & 0.77 & 0.61 & 0.22 & 0.47 \\
\hline Primary pollutants $\mathrm{PAH}$ & 0.48 & 0.60 & 0.90 & 0.81 & 0.37 & -0.11 & 0.14 \\
\hline $\mathrm{BC}$ & 0.63 & 0.56 & 0.82 & 0.83 & 0.69 & 0.18 & 0.50 \\
\hline $\mathrm{CO}$ & 0.52 & 0.54 & 0.62 & 0.74 & 0.61 & 0.29 & 0.51 \\
\hline $\mathrm{NO}_{2}$ & 0.45 & 0.64 & 0.61 & 0.72 & 0.57 & 0.20 & 0.44 \\
\hline \multicolumn{8}{|c|}{ AMS tracer ions ( $m / z$ value $)$} \\
\hline $\mathrm{CO}_{2}^{+}(44)$ & 0.32 & 0.38 & 0.41 & 0.47 & 0.84 & 0.75 & 0.92 \\
\hline $\mathrm{C}_{2} \mathrm{H}_{5} \mathrm{~N}^{+}(43)$ & 0.46 & 0.52 & 0.48 & 0.62 & 0.52 & 0.35 & 0.50 \\
\hline $\mathrm{C}_{2} \mathrm{H}_{4} \mathrm{O}_{2}^{+}(60)$ & 0.70 & 0.66 & 0.85 & 0.92 & 0.67 & 0.10 & 0.44 \\
\hline $\mathrm{C}_{3} \mathrm{H}_{5} \mathrm{O}_{2}^{+}(73)$ & 0.71 & 0.76 & 0.74 & 0.94 & 0.66 & 0.15 & 0.46 \\
\hline $\mathrm{C}_{3} \mathrm{H}_{3} \mathrm{O}^{+}(55)$ & 0.55 & 0.86 & 0.64 & 0.88 & 0.66 & 0.24 & 0.51 \\
\hline $\mathrm{C}_{3} \mathrm{H}_{7}^{+}(43)$ & 0.91 & 0.69 & 0.63 & 0.96 & 0.46 & 0.02 & 0.27 \\
\hline $\mathrm{C}_{3} \mathrm{H}_{7} \mathrm{~N}^{+}(57)$ & 0.60 & 0.57 & 0.56 & 0.74 & 0.78 & 0.33 & 0.63 \\
\hline $\mathrm{C}_{4} \mathrm{H}_{7}^{+}(55)$ & 0.85 & 0.78 & 0.65 & 0.98 & 0.49 & 0.04 & 0.30 \\
\hline $\mathrm{C}_{4} \mathrm{H}_{9}^{+}(43)$ & 0.95 & 0.62 & 0.61 & 0.94 & 0.42 & 0.00 & 0.24 \\
\hline $\mathrm{C}_{5} \mathrm{H}_{11}^{+}(57)$ & 0.96 & 0.59 & 0.60 & 0.92 & 0.41 & -0.01 & 0.23 \\
\hline $\mathrm{C}_{5} \mathrm{H}_{8} \mathrm{O}^{+}(84)$ & 0.58 & 0.93 & 0.54 & 0.90 & 0.50 & 0.09 & 0.33 \\
\hline $\mathrm{C}_{6} \mathrm{H}_{10} \mathrm{O}^{+}(98)$ & 0.57 & 0.95 & 0.51 & 0.89 & 0.41 & 0.02 & 0.24 \\
\hline $\mathrm{C}_{7} \mathrm{H}_{12} \mathrm{O}^{+}(112)$ & 0.57 & 0.89 & 0.58 & 0.88 & 0.53 & 0.09 & 0.35 \\
\hline $\mathrm{C}_{9} \mathrm{H}_{7}^{+}(115)$ & 0.82 & 0.74 & 0.72 & 0.96 & 0.18 & -0.05 & 0.10 \\
\hline $\mathrm{CHN}^{+}(27)$ & 0.47 & 0.47 & 0.58 & 0.63 & 0.73 & 0.53 & 0.73 \\
\hline $\mathrm{CN}^{+}(26)$ & 0.35 & 0.35 & 0.46 & 0.48 & 0.57 & 0.42 & 0.57 \\
\hline $\mathrm{CH}_{2} \mathrm{SO}_{2}^{+}(77)$ & 0.30 & 0.24 & 0.37 & 0.37 & 0.83 & 0.53 & 0.79 \\
\hline $\mathrm{CH}_{3} \mathrm{SO}_{2}^{+}(78)$ & 0.37 & 0.27 & 0.41 & 0.44 & 0.91 & 0.54 & 0.83 \\
\hline
\end{tabular}

BC: black carbon, AMS: aerosol mass spectrometer, PAH: polycyclic aromatic hydrocarbons. Values that are $r>0.7$ are boldfaced.

et al., 2004) are shown in Fig. 4c. Nitrate and sulfate had relatively different size distribution profiles, with the mode of sulfate being about $100 \mathrm{~nm}$ larger than the mode of ni- trate. A possible reason for this difference was likely that nitrate was mainly formed through photochemical reactions, whereas sulfate was more likely to be formed by aqueous- 


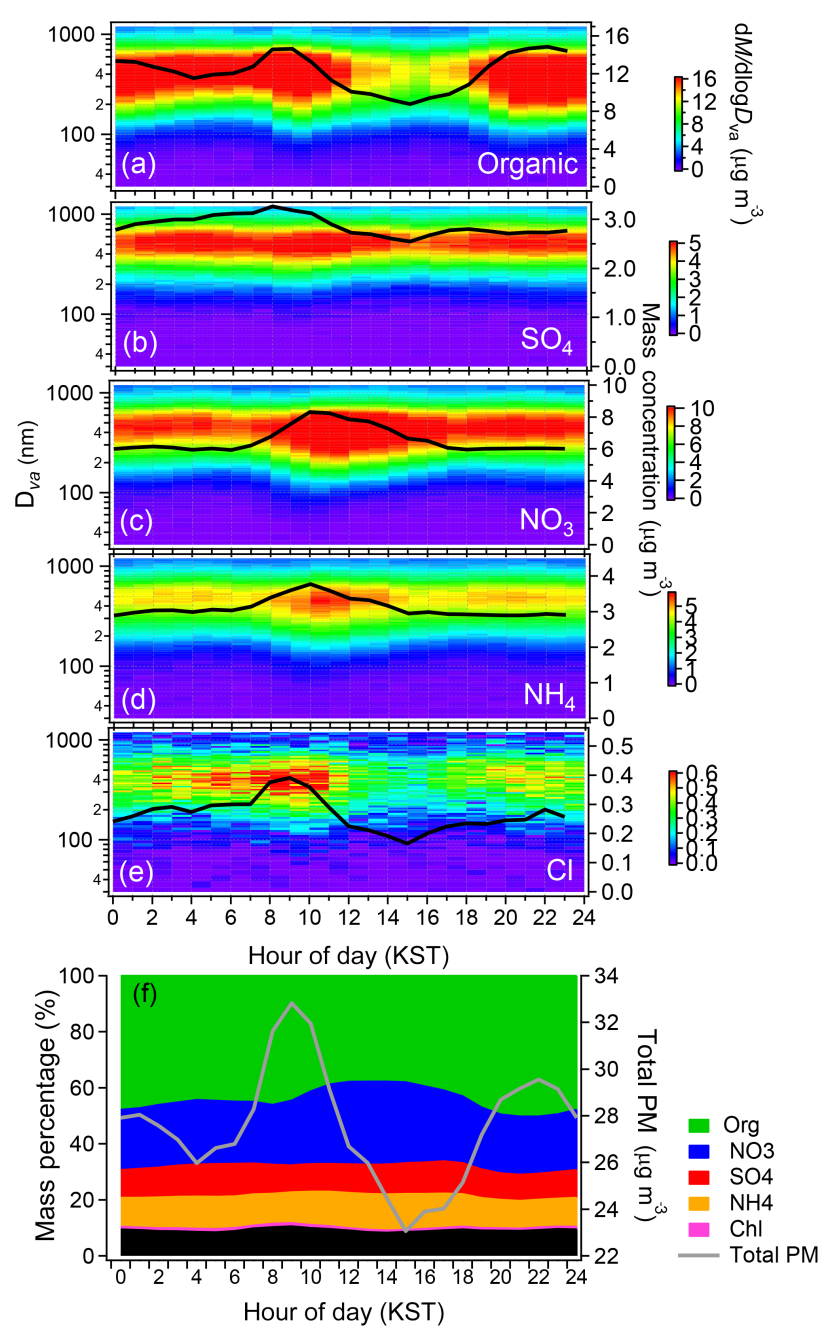

Figure 5. (a-e) Diurnal profiles, $1 \mathrm{~h}$ averaged, of mass-based size distributions of each of the nonrefractory submicrometer particulate matter $\left(\mathrm{NR}-\mathrm{PM}_{1}\right)$ species, colored by their mass concentration (left axis, $D_{\text {va }}$, vacuum aerodynamic diameter) and average diurnal profiles of each of the $\mathrm{PM}_{1}$ species (right axis); (f) average diurnal mass fractional contribution of each $\mathrm{PM}_{1}$ species to the total $\mathrm{PM}_{1}$ diurnal mass and the total $\mathrm{PM}_{1}$ mass loading.

phase reactions during this study. Another reason was that sulfate was overall more aged than nitrate. As discussed in previous sections, sulfate in Seoul was likely to be transported from regional sources at night, whereas nitrate was apparently formed mostly locally. The daily variations in the nitrate and sulfate size distributions (Figs. 5b, c; S4) further support the different formation processes for these two compounds. The size distributions of sulfate showed a prevalent droplet accumulation mode $\left(D_{\mathrm{va}}=500 \mathrm{~nm}\right)$ that stayed fairly constant compared to the one of nitrate (Fig. S4). However, the size distributions of nitrate became broader between 9:00 and 15:00, with significant changes in concentrations (Figs. 5c, S4a). In addition, nitrate size distribution was quite broad (Fig. 4c, d), similar to observations in various urban lo- cations (e.g., Sun et al., 2009, 2011a; Drewnick et al., 2004; Salcedo et al., 2006; Weimer et al., 2006; Young et al., 2016; Zhang et al., 2005b).

The average size distribution of OA was wider than that of the inorganic species, peaking at a $D_{\text {va }}$ of $\sim 400 \mathrm{~nm}$ (Fig. $4 \mathrm{c}$ ). The OA size distribution varied as a function of the time of day (Fig. 5a), with a broader profile extending to $D_{\text {va }}<$ $100 \mathrm{~nm}$ observed during the morning rush hour and at night when primary emissions are dominant. The wide size distribution of organics reflected the contribution made by both primary and secondary aerosols, i.e., the fine mode from primary aerosols and the accumulation mode from secondary formation. Similar observations were reported from China (e.g., Huang et al., 2010; Sun et al., 2010), and some urban areas in North America (Aiken et al., 2009; Alfarra et al., 2004; Drewnick et al., 2004; Ge et al., 2012b; Zhang et al., 2005b) and Europe (Allan et al., 2003; Dall'Osto et al., 2013).

\subsection{OA characteristics and source apportionment}

\subsubsection{Bulk composition and elemental ratios of $\mathrm{OA}$}

Atmospheric OA are composed of complex materials that originate from different sources and have undergone different atmospheric processes. Understanding the chemical composition and sources of OA is important for understanding the impacts of these aerosols.

Overall, OA from Seoul in winter was found to be composed of approximately $71 \%$ carbon, $18 \%$ oxygen, $9 \%$ hydrogen, and $2 \%$ nitrogen (Fig. 4e). The average carbon-normalized molecular formula of $\mathrm{OA}$ was $\mathrm{C}_{1} \mathrm{H}_{1.8} \mathrm{O}_{0.37} \mathrm{~N}_{0.022} \mathrm{~S}_{0.0009}$, yielding an average organic massto-carbon ratio $(\mathrm{OM} / \mathrm{OC})$ of 1.67. The largest component of the OA mass spectral signal was found to be the $\mathrm{C}_{x} \mathrm{H}_{y}^{+}$ ion family (57\%, Fig. 4e), followed by the $\mathrm{C}_{x} \mathrm{H}_{y} \mathrm{O}_{1}^{+}(25 \%)$ and $\mathrm{C}_{x} \mathrm{H}_{y} \mathrm{O}_{2}^{+}(11 \%)$ ion families, with smaller contributions from the $\mathrm{C}_{x} \mathrm{H}_{y} \mathrm{~N}_{\mathrm{p}}^{+}(4 \%), \mathrm{C}_{x} \mathrm{H}_{y} \mathrm{~N}_{\mathrm{p}} \mathrm{O}_{z}^{+}(2 \%)$, and $\mathrm{H}_{y} \mathrm{O}_{1}^{+}$ $(1 \%)$ ion families. The largest peak in the average OA spectrum was at $m / z=43$ (Fig. 4f), accounting for $8 \%$ of the total OA signal with a composition of $\mathrm{C}_{2} \mathrm{H}_{3} \mathrm{O}^{+}(49 \%)$, $\mathrm{C}_{3} \mathrm{H}_{7}^{+}(49 \%), \mathrm{CHON}^{+}(1 \%)$, and $\mathrm{C}_{2} \mathrm{H}_{5} \mathrm{~N}^{+}(1 \%)$. The second largest peak (6\% of the total OA signal) in the average OA spectrum was at $m / z=44$, which was dominated by the $\mathrm{CO}_{2}^{+}$ion $(86.7 \%)$, followed by $\mathrm{C}_{2} \mathrm{H}_{4} \mathrm{O}^{+}(7.8 \%)$, $\mathrm{C}_{2} \mathrm{H}_{6} \mathrm{~N}^{+}(2.7 \%), \mathrm{CH}_{2} \mathrm{NO}^{+}(2.6 \%)$, and $\mathrm{C}_{3} \mathrm{H}_{8}^{+}(0.2 \%)$. The peak at $m / z=60$ was composed almost entirely of $\mathrm{C}_{2} \mathrm{H}_{4} \mathrm{O}_{2}^{+}$ (94\%) and $88 \%$ of the peak at $m / z=73$ was composed of $\mathrm{C}_{3} \mathrm{H}_{5} \mathrm{O}_{2}^{+}$, both of which are the tracers of wood burning (Aiken et al., 2008; Alfarra et al., 2007). The peak at $m / z=57$, which is used as a tracer for hydrocarbon-like organics from vehicle emissions (Zhang et al., 2005a), accounted for $4 \%$ of the total OA signal and was composed predominantly of $\mathrm{C}_{4} \mathrm{H}_{9}^{+}(75 \%)$ and $\mathrm{C}_{3} \mathrm{H}_{5} \mathrm{O}^{+}(22 \%)$ in this study. 

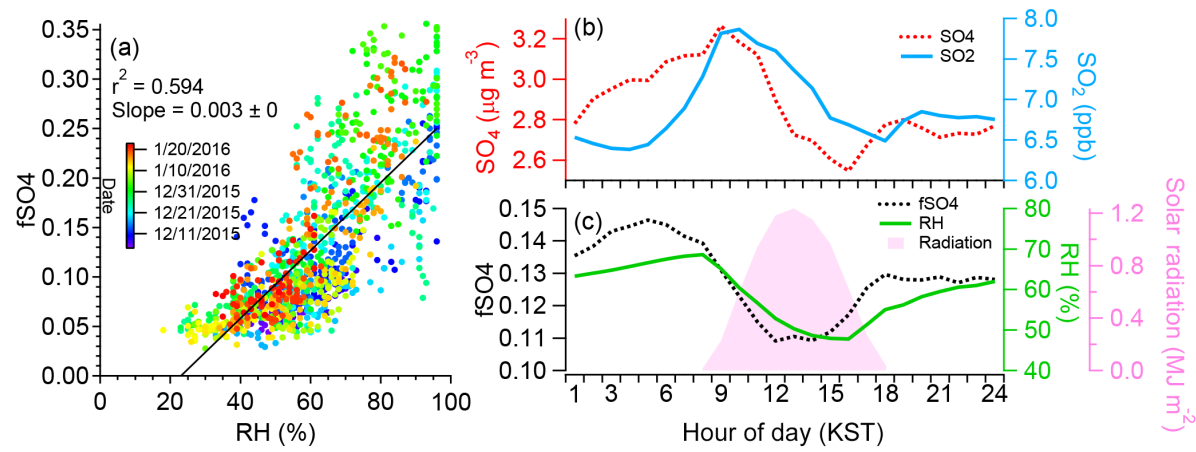

Figure 6. (a) Scatterplot of the variations in $f \mathrm{SO}_{4}$ ratios as a function of RH. (b) Diurnal profiles, $1 \mathrm{~h}$ averaged, of $\mathrm{SO}_{2}$ and $\mathrm{SO}_{4}$, and (c) $1 \mathrm{~h}$ averaged diurnal profiles of $f \mathrm{SO}_{4}, \mathrm{RH}$, and solar radiation. The solar radiation measurement site is located at $20 \mathrm{~km}$ away from the measurement site.
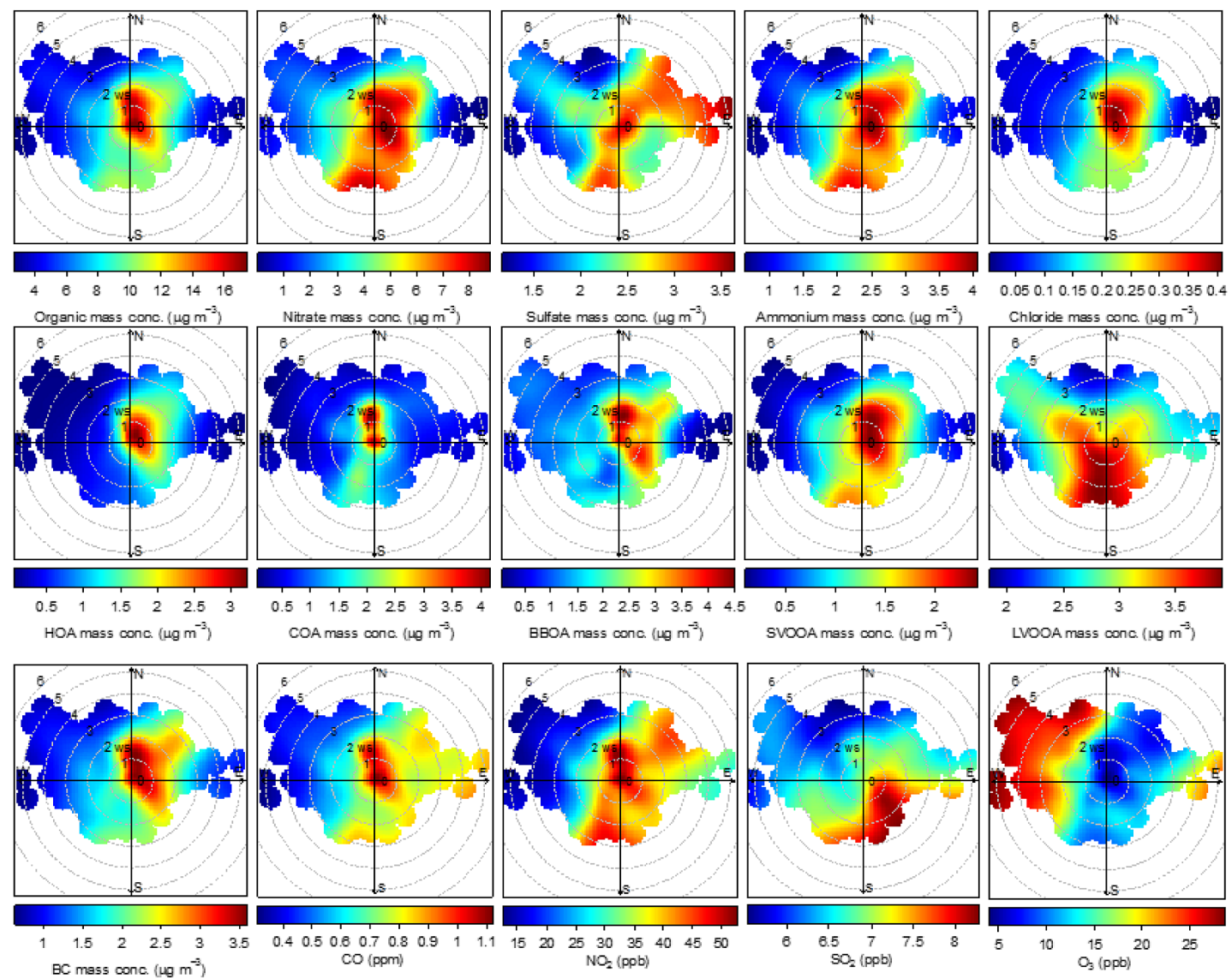

Figure 7. Polar plots of hourly averaged $\mathrm{PM}_{1}$ species concentrations (top row), mass concentrations of the five OA factors identified from PMF analysis (middle row), and the mixing ratios of various gas-phase species as a function of WS and direction.

The time series of the $\mathrm{H} / \mathrm{C}, \mathrm{O} / \mathrm{C}, \mathrm{N} / \mathrm{C}$, and $\mathrm{S} / \mathrm{C}$ ratios of $\mathrm{OA}$ are shown in Fig. 3e and $\mathrm{f}$. The $\mathrm{O} / \mathrm{C}$ ratio of an $\mathrm{OA}$ indicates its average oxidation level, and more aged and oxidized organics tend to have higher $\mathrm{O} / \mathrm{C}$ ratios (Aiken et al., 2008; Jimenez et al., 2009). The $\mathrm{O} / \mathrm{C}$ varied substantially during this study, ranging from 0.05 to 0.63 , and the average $\mathrm{O} / \mathrm{C}$ ratio was $0.37 \pm 0.09$. The average $\mathrm{H} / \mathrm{C}$ ratio was $1.79 \pm 0.07(1.60-2.29)$ and the average OM / OC was $1.67 \pm 0.12(1.26-2.03)$. These values, which were calculated using the updated elemental analysis method (Canagaratna et al., 2015), are within the range of revised values observed at other urban locations (Canagaratna et al., 2015 and references within). Upon examining the diurnal patterns, we also found that the $\mathrm{O} / \mathrm{C}$ and $\mathrm{OM} / \mathrm{OC}$ ratios started to increase in 

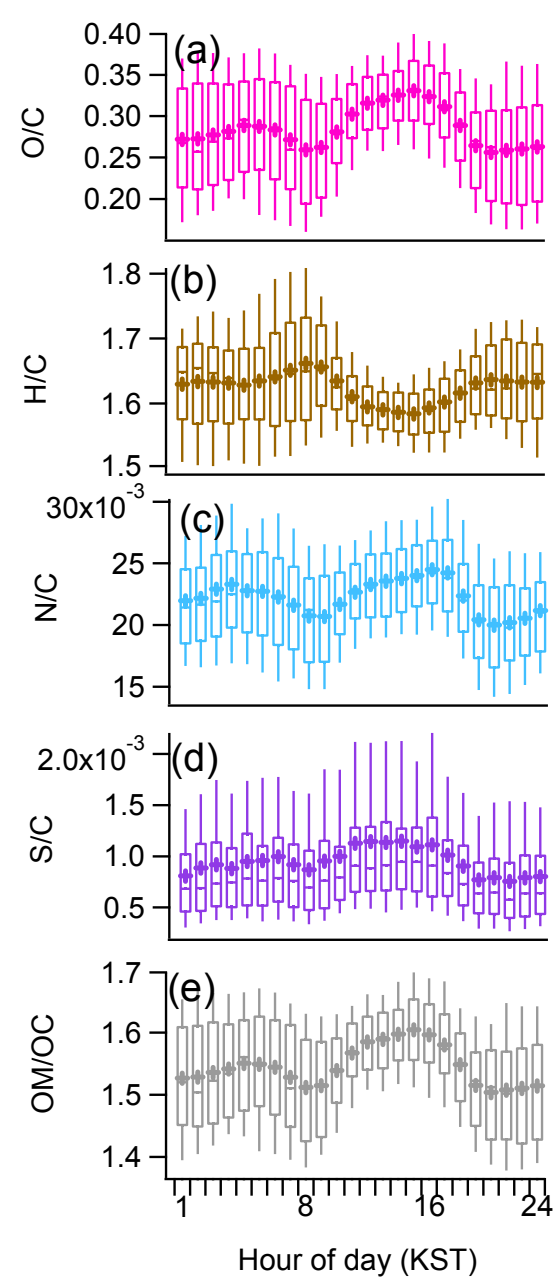

Figure 8. (a-e) Average diurnal profiles of the organic matter-toorganic carbon $(\mathrm{OM} / \mathrm{OC})$, oxygen-to-carbon $(\mathrm{O} / \mathrm{C})$, hydrogento-carbon $(\mathrm{H} / \mathrm{C})$, nitrogen-to-carbon $(\mathrm{N} / \mathrm{C})$, and sulfur-to-carbon (S / C) ratios of OA, where the $\mathrm{O} / \mathrm{C}, \mathrm{H} / \mathrm{C}$, and $\mathrm{OM} / \mathrm{OC}$ elemental ratios were determined using the updated method (Canagaratna et al., 2015).

the morning and peaked in the afternoon (Fig. $8 \mathrm{a}$ and e). The lowest value of both parameters occurred at around 8:00 due to enhanced vehicle emissions during morning rush hours coupled with low BL height, which was also evident in the diurnal profile of the $\mathrm{H} / \mathrm{C}$ ratio (Fig. 8b). However, during the day (8:00-16:00), the $\mathrm{O} / \mathrm{C}$ ratio generally increased and the $\mathrm{H} / \mathrm{C}$ ratio decreased, suggesting that SOA production or mixing with more aged aerosols from regional sources was important during the day and outweighed the emissions POA. The decrease in the $\mathrm{OM} / \mathrm{OC}$ and $\mathrm{O} / \mathrm{C}$ ratios as well as the increase in $\mathrm{H} / \mathrm{C}$ ratio in the late evening (19:00-20:00) was consistent with an enhancement of POA emissions during the evening rush hour and dinner time.

Although organic ions containing nitrogen and sulfur had relatively low abundance (average $\mathrm{N} / \mathrm{C}=0.018$; average $\mathrm{S} / \mathrm{C}=0.001)$, both nitrogen-to-carbon $(\mathrm{N} / \mathrm{C})$ and sulfur- to-carbon $(\mathrm{S} / \mathrm{C})$ ratios showed distinct diurnal profiles where N / C was enhanced during the day (8:00-16:00) and increased again in the late evening (19:00). This suggests that particulate nitrogen-containing compounds in Seoul were probably from both primary emissions and secondary formation. However, S / C showed relatively strong enhancement during the day (8:00-16:00), suggesting that sulfurcontaining organics were mainly formed by secondary processes during the day. This is further confirmed by considering the correlation between different OA factors vs. AMS spectral ions; nitrogen-containing ions had good correlation with both POA and SOA factors, whereas sulfur-containing ions had good correlation only with OOAs (Fig. S5; see Sect. 3.3.2).

\subsubsection{Organic aerosol source apportionment and characteristics of $\mathrm{OA}$ factors}

Separation of distinct organic aerosol sources can be achieved through the application of multivariate models such as PMF (Lanz et al., 2007; Ulbrich et al., 2009; Zhang et al., 2011). In this study, five OA factors were

determined, consisting of three POA factors (HOA, COA, and $\mathrm{BBOA}$ ) and two SOA factors (LV-OOA and SV-OOA). The $\mathrm{O} / \mathrm{C}$ ratios for the factors were $\mathrm{LV}-\mathrm{OOA}=0.68, \mathrm{SV}$ $\mathrm{OOA}=0.56, \mathrm{BBOA}=0.34, \mathrm{COA}=0.14$, and $\mathrm{HOA}=0.06$. The elemental ratios of the factors were estimated using the updated method reported by Canagaratna et al. (2015). A comparison of the $\mathrm{O} / \mathrm{C}$ and $\mathrm{H} / \mathrm{C}$ ratios of each $\mathrm{PMF}$ factor, as determined by the methods of Aiken et al. (2008) and Canagaratna et al. (2015), can be found in Table S1 in the Supplement. An overview of the chemical composition of and temporal variations in the five factors is shown in Figs. 9, 10 , and S7. The five factors made similar contributions to total OA mass, with LV-OOA (26\%) representing the largest fraction of the OA mass and the smallest fraction accounted for by SV-OOA $(15 \%)$. BBOA, COA, and HOA accounted for 23,20 , and $16 \%$ of the total OA mass, respectively. Together, primary components on average accounted for $59 \%$ of the total OA mass and SOA accounted for $41 \%$ (Fig. 10k). The chemical composition of and temporal variations in each factor are discussed in detail below.

\section{Hydrocarbon-like OA (HOA)}

Alkyl fragments $\left(\mathrm{C}_{n} \mathrm{H}_{2 n+1}^{+}\right.$and $\left.\mathrm{C}_{n} \mathrm{H}_{2 n-1}^{+}\right)$made a substantial contribution to the HOA factor, with major peaks at $m / z 41$, 43,55 , and 57 , which were mostly composed of $\mathrm{C}_{3} \mathrm{H}_{5}^{+}$, $\mathrm{C}_{3} \mathrm{H}_{7}^{+}, \mathrm{C}_{4} \mathrm{H}_{7}^{+}$, and $\mathrm{C}_{4} \mathrm{H}_{9}^{+}$ions, respectively (Fig. 10a). These major peaks and the overall picket-fence fragmentation pattern resulting from the $\mathrm{C}_{n} \mathrm{H}_{2 n+1}^{+}$ions are typical features of the HOA spectra reported in other studies and are due to the association of these aerosols with fossil fuel combustion (e.g., Alfarra et al., 2007; Lanz et al., 2008; Sun et al., 2011b; Zhang et al., 2005a; Huang et al., 2010; Mor- 


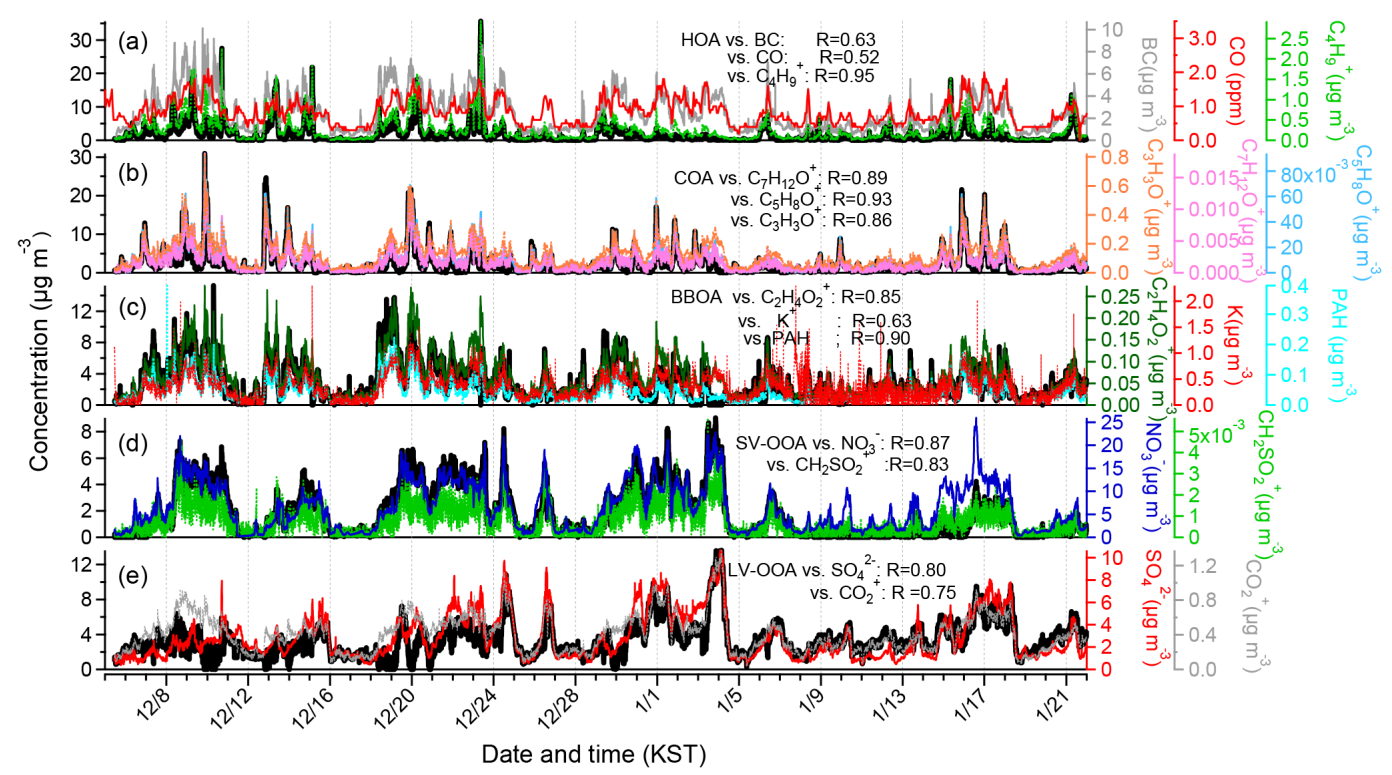

Figure 9. Overview of the results from PMF analysis, including the time series of each of the OA factors and various tracer species.
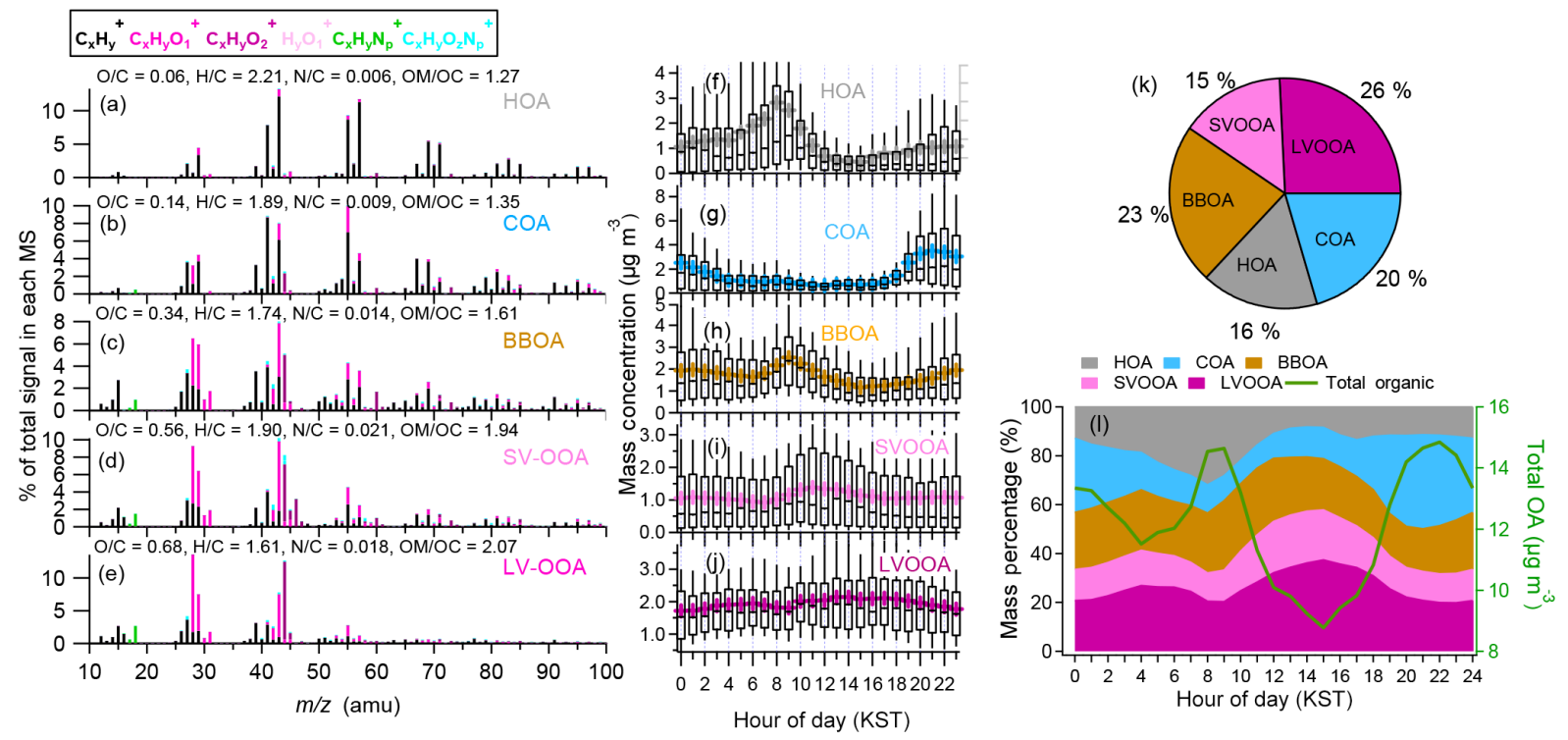

Figure 10. Overview of the results from PMF analysis, including high-resolution mass spectra of the (a) hydrocarbon-like organic aerosol (HOA), (b) cooking OA (COA), (c) biomass burning OA (BBOA), (d) semivolatile oxygenated OA (SV-OOA), and (e) low-volatility oxygenated OA (LV-OOA) colored by different ion families. (f-i) Average diurnal profiles of each of the OA factors (the 90th and 10th percentiles are denoted by the whiskers above and below the boxes. The 75th and 25 th percentiles are denoted by the top and bottom of the boxes. The median values are denoted by the horizontal line within the box, and the mean values are denoted by the colored markers). (k) Compositional pie chart of the average fractional contribution of each of the OA factors to the total OA over the campaign; (l) average diurnal mass fractional contribution of each of the OA factors to the total OA diurnal mass and the total OA mass loading.

gan et al., 2010; $\mathrm{Ng}$ et al., 2011). In addition, strong correlations were observed between the time series of HOA and the $\mathrm{C}_{n} \mathrm{H}_{2 n+1}^{+}$and $\mathrm{C}_{n} \mathrm{H}_{2 n-1}^{+}$ions, e.g., $\mathrm{C}_{3} \mathrm{H}_{7}^{+}(r=0.91), \mathrm{C}_{4} \mathrm{H}_{7}^{+}$ $(r=0.85), \mathrm{C}_{4} \mathrm{H}_{9}^{+}(r=0.95)$, and $\mathrm{C}_{5} \mathrm{H}_{11}^{+}(r=0.96)$ (Fig. 9a and Table 2). Due to the dominance of chemically reduced hydrocarbon species, the $\mathrm{O} / \mathrm{C}$ ratio of the HOA in this study was low (0.06), whereas the $\mathrm{H} / \mathrm{C}$ ratio was high (2.21). The $\mathrm{O} / \mathrm{C}$ ratio of HOA in this study was similar to the updated values of HOA (0.05-0.25) from other studies (Canagaratna et al., 2015).

The regular enhancement of HOA around 7:00-9:00, as shown in its diurnal profile (Fig. 10f), was consistent with 
the occurrence of morning rush-hour traffic in Seoul and the association of HOA with vehicle emissions. HOA concentration decreased rapidly from 8:00 to 12:00 and remained low in the afternoon, mainly due to dilution associated with rising BL height. A slow increase in HOA concentration began at $\sim 16: 00$ and persisted until the next morning, suggesting that the shallow BL enhanced the gradual accumulation of the pollutants from vehicle emissions. However, the correlations of the time series of HOA with gaseous tracers of primary emissions (i.e., $\mathrm{BC}, \mathrm{NO}_{2}$, and $\mathrm{CO}$ ) were only moderate (Fig. 9a and Table 2), mainly because these pollutants are emitted not only from vehicular sources but also from other combustion sources, e.g., biomass burning. Indeed, the correlations are much stronger between these pollutants and total $\mathrm{POA}(=\mathrm{HOA}+\mathrm{COA}+\mathrm{BBOA})(r=0.7-0.81$, Fig. 11 and Table 2).

In this study, major differences were observed between weekdays and weekends for HOA, including other primary species, e.g., BC and POA factors (Fig. S10). For example, the diurnal patterns of HOA and BC changed significantly between the weekdays and weekends and a general decrease in the morning rush-hour peak over the weekend was observed, likely due to a decrease in commuting activities because people were more likely to be at home. This weekend effect is a typical urban feature, which was observed in Fresno (Young et al., 2016) and the Northeastern US (Zhou et al., 2016b), as well.

\section{Cooking OA (COA)}

COA, as resolved by AMS OA spectra, has been widely reported in urban areas with high population densities (He et al., 2010; Huang et al., 2010; Mohr et al., 2012; Sun et al., 2011b; Young et al., 2016; Ge et al., 2012a; Wang et al., 2016; Xu et al., 2014); however no results have yet been reported from Seoul. In this study, COA was found to account for $20 \%$ of the total OA mass, which is higher than HOA (Fig. 10k). The diurnal pattern of COA displayed a large evening peak, with a maximum concentration occurring at 19:00, i.e., dinner time. Elevated COA concentration and larger fractional contribution to OA mass were observed throughout the night (Fig. 10g, 1).

Similar to HOA, the mass spectrum of COA in this study also contained many alkyl fragments, but to a lesser extent ( $75.8 \%$ of the total signal in the COA spectrum compared to $87.9 \%$ of the total signal in the HOA spectrum) (Fig. 10b). However, COA contains significantly larger amounts of oxygen-containing ions than $\mathrm{HOA}$ (e.g., $\mathrm{C}_{x} \mathrm{H}_{y} \mathrm{O}_{1}^{+}=15.4 \%$ vs. $7.6 \%$ and $\mathrm{C}_{x} \mathrm{H}_{y} \mathrm{O}_{2}^{+}=5.1 \%$ vs. $2.3 \%$ ) (Fig. 10a), and thus has a higher $\mathrm{O} / \mathrm{C}$ ratio $(0.14)$ and a lower $\mathrm{H} / \mathrm{C}$ ratio (1.89). The OM / OC ratio was 1.3 and the $\mathrm{H} / \mathrm{C}$ ratio was 1.78 for COA. The observed $\mathrm{O} / \mathrm{C}$ ratio $(0.14)$ of COA in Seoul was at the lower end of the range (0.14-0.27) of the revised, measured $\mathrm{O} / \mathrm{C}$ ratio of COA in other studies, e.g., Barcelona (0.27) (Mohr et al., 2012), New York
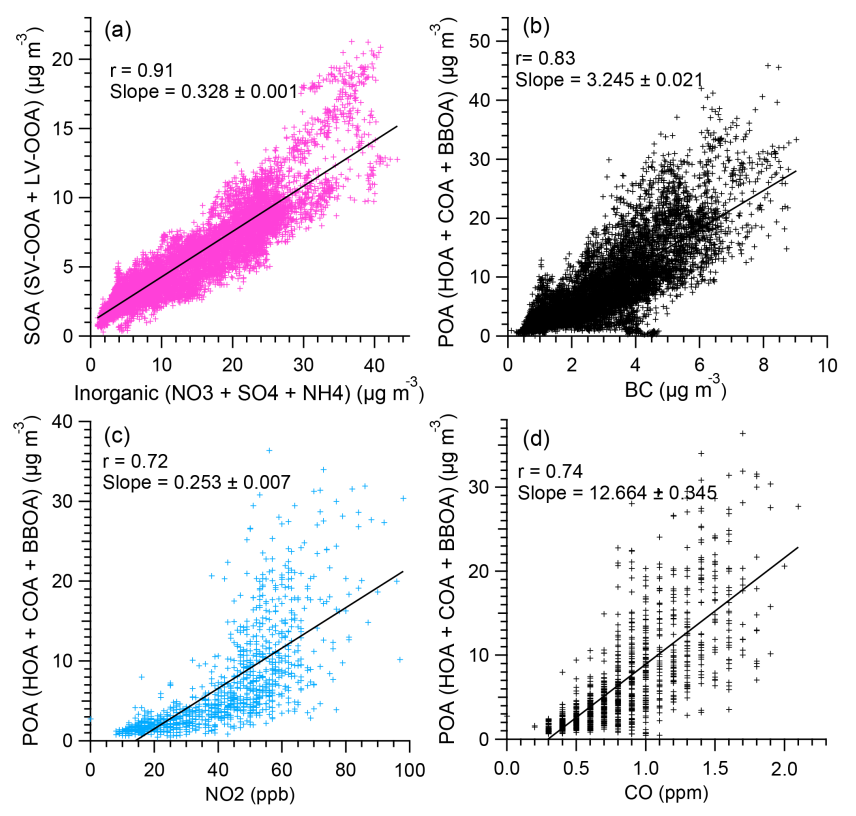

Figure 11. Scatterplot between (a) SOA and sum of inorganic $\left(\mathrm{NO}_{3}+\mathrm{SO}_{4}+\mathrm{NH}_{4}\right)$, (b) POA and $\mathrm{BC}$, (c) POA and $\mathrm{NO}_{2}$, and (d) POA and CO.

City (NYC) (0.23) (Sun et al., 2011a), and Fresno (0.14 in 2010; Ge et al., 2012b; and 0.19 in 2013; Young et al., 2016). Previous studies suggest that $\mathrm{C}_{3} \mathrm{H}_{3} \mathrm{O}^{+}(\mathrm{m} / z$ 55) and $\mathrm{C}_{3} \mathrm{H}_{5} \mathrm{O}^{+}(\mathrm{m} / \mathrm{z}, 57)$ were major fragments of aliphatic acids (e.g., linoleic acid and palmitic acid) in cooking oils or animal fat and therefore used these ions as key tracers for identifying the presence of aerosols from cooking-related activities (He et al., 2004; Adhikary et al., 2010; Mohr et al., 2009; Zhao et al., 2007). In addition, $\mathrm{C}_{5} \mathrm{H}_{8} \mathrm{O}^{+}(\mathrm{m} / z$ 84) and $\mathrm{C}_{6} \mathrm{H}_{10} \mathrm{O}^{+}(\mathrm{m} / \mathrm{z} 98)$ have been proposed as AMS tracers for COA as well (Ge et al., 2012a; Sun et al., 2011b). In this study, the time series of COA correlated well with these ions, e.g., $\mathrm{C}_{3} \mathrm{H}_{3} \mathrm{O}^{+}(r=0.86), \mathrm{C}_{5} \mathrm{H}_{8} \mathrm{O}^{+}(r=0.93)$, $\mathrm{C}_{7} \mathrm{H}_{12} \mathrm{O}^{+}(r=0.89)$, and $\mathrm{C}_{6} \mathrm{H}_{10} \mathrm{O}^{+}(r=0.95)$ (Fig. $9 \mathrm{~b}$ and Table 2), and COA was a major contributor to the signals of $\mathrm{C}_{5} \mathrm{H}_{8} \mathrm{O}^{+}, \mathrm{C}_{6} \mathrm{H}_{10} \mathrm{O}^{+}$, and $\mathrm{C}_{7} \mathrm{H}_{12} \mathrm{O}^{+}$, accounting for 57, 69, and $52 \%$, respectively, of their signals (Fig. S6). To show the chemical difference between COA and other OA factors, Mohr et al. (2012) used the relationships between the fractions of OA signals at $m / z 55$ and $m / z 57$ (i.e., $f_{55}$ and $f_{57}$ ) or between those of $\mathrm{C}_{3} \mathrm{H}_{3} \mathrm{O}^{+}$and $\mathrm{C}_{3} \mathrm{H}_{5} \mathrm{O}^{+}$(i.e., $f \mathrm{C}_{3} \mathrm{H}_{3} \mathrm{O}^{+}$ and $f \mathrm{C}_{3} \mathrm{H}_{5} \mathrm{O}^{+}$) after subtracting the contributions from the oxygenated $\mathrm{OA}$ factors and found that the ratios between $m / z 55\left(\mathrm{C}_{4} \mathrm{H}_{7}^{+}+\mathrm{C}_{3} \mathrm{H}_{3} \mathrm{O}^{+}\right)$and $m / z 57\left(\mathrm{C}_{4} \mathrm{H}_{9}^{+}+\mathrm{C}_{3} \mathrm{H}_{5} \mathrm{O}^{+}\right)$ in COA were much higher (2.2-2.8) than the ratios (0.9-1.1) in other POAs (e.g., HOA and BBOA). The COA resolved in Seoul in this study had an $m / z$ 55-to- $m / z 57$ ratio of 2.2, which is within the range of the values for COA reported in Mohr et al. (2012) (Fig. S9). In addition, the ratios be- 
tween $f_{55}$ and $f_{57}$ for $\mathrm{OA}$ in Seoul increased proportionally as the fractional contribution of COA to total OA increased (Fig. S9b), with a V shape indicated by the two edges defined by the COA and the HOA factors from several urban AMS data sets (Mohr et al., 2012). These observations together confirm the identification of COA at Seoul.

\section{Biomass burning OA (BBOA)}

Wood combustion was found to be another important POA source $(23 \%$, Fig. 10k) in Seoul during winter, in addition to vehicle and cooking emissions. BBOA is typically prevalent during winter in locations where wood is used for residential heating (Ge et al., 2012a; Crippa et al., 2013; Zhang et al., 2015; Young et al., 2016). The mass spectrum of BBOA showed strong signals of oxygenated ions $\left(\mathrm{C}_{x} \mathrm{H}_{y} \mathrm{O}_{1}^{+}\right.$: $27.1 \%$ of total BBOA signal and $\mathrm{C}_{x} \mathrm{H}_{y} \mathrm{O}_{2}^{+}: 10.6 \%$ of total BBOA signal) and was more oxidized than $\mathrm{HOA}$ and $\mathrm{COA}$ (Fig. 10). Among the three POA factors, the $\mathrm{O} / \mathrm{C}$ ratio of BBOA was the highest $(0.34)$ and the $\mathrm{H} / \mathrm{C}$ ratio was the lowest (1.74), similar to the results reported in several previous studies (e.g., Aiken et al., 2009; Ge et al., 2012a; Mohr et al., 2012). An analysis of the OA spectra (Fig. 10c) revealed the typical features of BBOA, with dominant peaks at $m / z 60\left(100 \%\right.$ being $\left.\mathrm{C}_{2} \mathrm{H}_{4} \mathrm{O}_{2}^{+}\right)$and $m / z 73$ (95\% being $\mathrm{C}_{3} \mathrm{H}_{5} \mathrm{O}_{2}^{+}$), which are known fragments of levoglucosan and related species (e.g., mannosan and galactosan) (Cubison et al., 2011). Scatterplots of $f_{44}$ vs. $f_{60}$ indicate a higher $f_{60}$ and lower $f_{44}$ (i.e., toward the center of the triangle area of the biomass burning plumes) as the relative importance of BBOA to the total OA increased (Fig. S9). The $f_{44}$ and $f_{60}$ of BBOA (0.05 vs. 0.016$)$ in this study were also within the range of values found for the other ambient BBOA factors or biomass burning aerosols from chamber studies. HOA and COA, in contrast, had much lower $f_{60}$ values $(<0.01)$. The time series of BBOA correlated well with $\mathrm{C}_{2} \mathrm{H}_{4} \mathrm{O}_{2}^{+}(r=0.85)$ and $\mathrm{C}_{3} \mathrm{H}_{5} \mathrm{O}_{2}^{+}(r=0.74)$ (Fig. 9d and Table 2) as well as other biomass burning tracer species, including potassium $(r=0.63)$ and $\mathrm{BC}(r=0.82)$. BBOA also correlated well with nitrogen-containing species, particularly $\mathrm{C}_{3} \mathrm{H}_{4} \mathrm{~N}^{+}(r=0.75), \mathrm{C}_{2} \mathrm{H}_{4} \mathrm{~N}^{+}(r=0.70)$, and $\mathrm{CHN}^{+}$ $(r=0.58)$, which was consistent with the emissions of nitriles from biomass burning activities (Simoneit et al., 2003). There was also a strong correlation between the concentration of polycyclic aromatic hydrocarbons (PAHs; $r=0.90$ ) and BBOA, indicating that biomass burning was a main source of PAH in Seoul in winter. Similarly, in winter in Fresno, California, it was found that BBOA correlates well with N-containing ions and PAHs (Ge et al., 2012a; Young et al., 2016). Given that PAHs are byproducts of incomplete combustion, many of which are mutagenic and carcinogenic (Dzepina et al., 2007; Hannigan et al., 1998; Marr et al., 2006), our findings suggest that adverse health effects associated with biomass burning emissions should be of concern during winter in the Seoul region.
BBOA was the most abundant primary OA in Seoul during this study, accounting for $39 \%$ of the POA mass and $23 \%$ of the total OA mass. However, biomass burning is not the main fuel for residential heating in Seoul, and thus the BBOA observed in this study must have originated from other woodburning activities, either locally or regionally. The fact that the observed BBOA was relatively oxidized $(\mathrm{O} / \mathrm{C}=0.34)$, with a large contribution from $m / z 44\left(f_{44}=5.1 \%\right)$, was consistent with the observations of more aged BBOA instead of primary wood-stove emissions (Crippa et al., 2013; Zhang et al., 2015; Zhou et al., 2016a). The diurnal profile of BBOA showed an enhancement at around 9:00 and a background BBOA concentration of $\sim 1 \mu \mathrm{g} \mathrm{m}^{-3}$. Given that the polar plot of BBOA showed high concentrations at both low and high wind speeds (Fig. 7), the sources of BBOA in Seoul likely include both local and regional wood-burning activities. Local wood-burning activities were possibly for the purposes of heating open and public areas (e.g., construction areas, market), disposing of leaves and woody trash in the city, and heating some residences. Regional sources of BBOA are possibly from open biomass burning in agricultural areas near Seoul (Heo et al., 2009) and transport from North Korea or from Russia (Jung et al., 2016).

\section{Semivolatile and low-volatile oxygenated OA (SV-OOA and LV-OOA)}

In addition to the three POA factors, two OOA factors were identified and were found to account for an average of $41 \%$ of the OA mass (Fig. 10k). OOA is ubiquitous and dominant in the atmosphere (Jimenez et al., 2009; Zhang et al., 2007a) but usually accounts for less than half of the OA mass observed during winter in urban locations such as NYC, Tokyo, Fresno, and Manchester (Zhang et al., 2007b).

In many cases, OOA can be further separated into a lowvolatile-more-oxygenated OOA (LV-OOA-MO-OOA) and a semivolatile-less-oxygenated OOA (SV-OOA-LO-OOA), which represent different degrees of aging and oxidation (Jimenez et al., 2009; $\mathrm{Ng}$ et al., 2010, and reference therein; Setyan et al., 2012; Xu et al., 2015). In this study, two OOA factors, SV-OOA and LV-OOA, were observed to account for 15 and $26 \%$ of the total OA mass, respectively (Fig. 10k). As shown in the triangle plots in Fig. S9, SVOOA $(\mathrm{O} / \mathrm{C}=0.56, \mathrm{H} / \mathrm{C}=1.90)$ resides within the region representing fresher SOA, with a low $f_{44}$, and LV-OOA $(\mathrm{O} / \mathrm{C}=0.68, \mathrm{H} / \mathrm{C}=1.61)$ was similar to aged and highlyoxidized OA, with a high $f_{44}$. It has been observed that fresh OOA becomes increasingly more oxidized and less volatile through aging processes in the atmosphere resulting in LVOOA. Furthermore, the evolution of SOA is regarded as a continuum of oxidation. The mass spectra of both LV-OOA and SV-OOA were very similar to the spectra of OOA factors reported in other cities (e.g., Hayes et al., 2013; Mohr et al., 2012; Zhang et al., 2014). 
Comparisons between the time series of SV-OOA and LVOOA with gaseous species, aerosol species, and meteorological parameters further confirmed their secondary nature. As shown in Table 2, SV-OOA and LV-OOA strongly correlated with nitrate $(r=0.87$ and 0.63 , respectively) and sulfate ( $r=0.71$ and 0.80 , respectively), whereas the correlations between POA factors and the inorganic aerosol species were low $(r=0.09-0.41)$. The Pearson's correlation coefficient between total OOA $(=\mathrm{SV}-\mathrm{OOA}+\mathrm{LV}-\mathrm{OOA})$ and the sum of secondary inorganic aerosols $\left(\mathrm{NO}_{3}^{-}+\mathrm{SO}_{4}^{2-}+\mathrm{NH}_{4}^{+}\right)$ was as high as 0.91 (Fig. 11a). These results confirm the association of SV-OOA and LV-OOA with SOA.

As discussed above, sulfate in Seoul is mainly associated with regional sources, while nitrate is often formed more locally due to the intense urban emissions of $\mathrm{NO}_{x}$. The better correlations between SV-OOA and nitrate and between LV-OOA and sulfate (Table 2) suggest that SV-OOA likely had more local sources whereas LV-OOA likely had more regional sources. Furthermore, SV-OOA correlated more strongly with methanesulfonic acid (MSA), an SOA species that tends to be semivolatile. As shown in Table 2, the correlations of SV-OOA and LV-OOA with AMS spectral ions for MSA (Ge et al., 2012a), i.e., $\mathrm{CH}_{3} \mathrm{SO}_{2}^{+}(r=0.90$ and 0.53 , respectively), and $\mathrm{CH}_{2} \mathrm{SO}_{2}^{+}(r=0.83$ and 0.53 , respectively) corroborated the different natures of SV-OOA (fresher, more local) and LV-OOA (aged, more regional). The diurnal profiles of SV-OOA and LV-OOA also reflected the features of local versus regional sources (Fig. 10i,j). SV-OOA concentration had a clear peak during midmorning to afternoon (10:00-11:00, Fig. 10i); however, LV-OOA concentration was relatively constant throughout the day, suggesting regional sources of this aerosol component (Fig. 10j). Similar observations were also reported in other areas such as North America (e.g., Budisulistiorini et al., 2015; Sun et al., 2011b; Woody et al., 2016; Zhou et al., 2016b; Zhang et al., 2005b), Europe (e.g., Mohr et al., 2012; Young et al., 2015), and Asia (e.g., Huang et al., 2010; Jiang et al., 2015; Wang et al., 2016). Finally, the polar plots of both OOAs showed more dispersed features compared to the POA factors, especially HOA and COA, but SV-OOA appeared to have a stronger association with local processes since its high concentrations tended to be associated with lower wind speed, compared to LV-OOA (Fig. 7).

\subsection{Relative importance of local and regional influences on air quality in Seoul during winter}

In an effort to improve ambient air quality, the Korean government enacted the Special Act on Seoul Metropolitan Air Quality Improvement to regulate the concentrations of key pollutants such as $\mathrm{SO}_{2}, \mathrm{CO}, \mathrm{NO}_{2}, \mathrm{O}_{3}, \mathrm{PM}$, and $\mathrm{Pb}$ (lead) in 2005. However, Seoul is still facing poor air quality problems, especially in terms of high concentrations of $\mathrm{PM}_{2.5}$ and $\mathrm{O}_{3} . \mathrm{PM}_{2.5}$ has been one of the primary concerns due to its detrimental impacts on human health as well as on visibility.

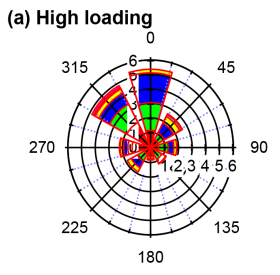

Avg. WS $=0.99 \mathrm{~m} \mathrm{~s}$, Avg. $\mathrm{RH}=71 \%$

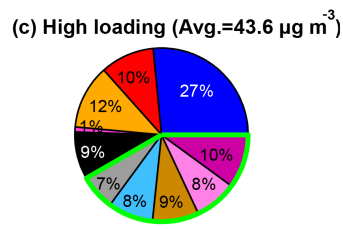

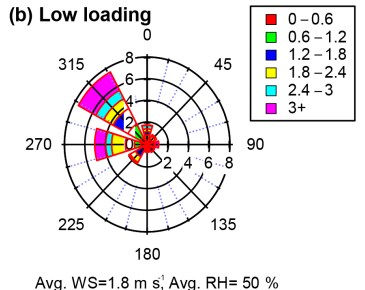

Avg. WS $=1.8 \mathrm{~m} \mathrm{~s}$, Avg. $\mathrm{RH}=50 \%$ (d) Low loading (Avg.=12.6 $\mu \mathrm{g} \mathrm{m}^{-3}$ )
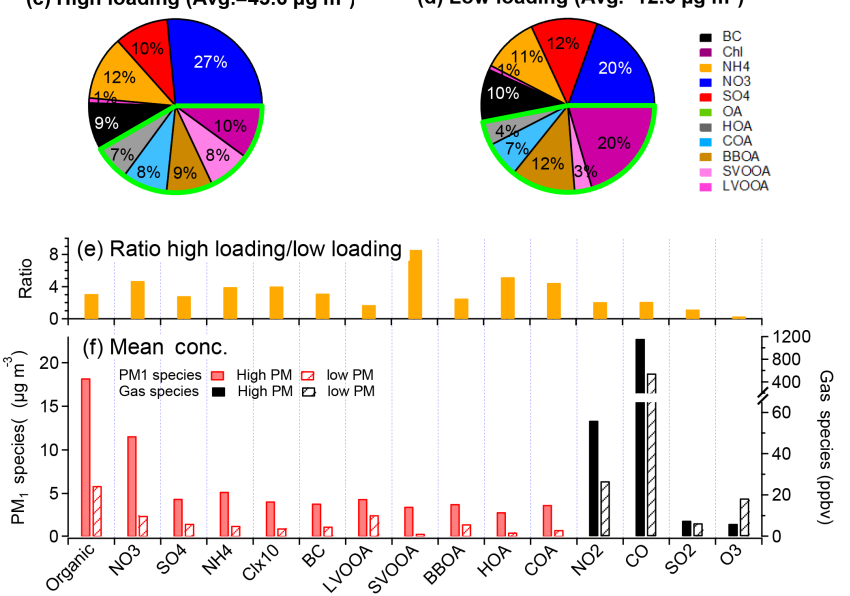

Figure 12. Comparisons of averaged properties measured during high particulate matter (PM), loading, and low-PM loading periods; $(\mathbf{a}, \mathbf{b})$ wind rose plots, colored by wind speed for each different period; (c, d) fractional contributions of each species to the total $\mathrm{PM}_{1}$ (nonrefractory $\mathrm{PM}_{1}$ plus $\mathrm{BC}$ ) mass; (e) ratios of absolute concentrations of each $\mathrm{PM}_{1}$ and gas species during high-loading and low-loading periods; (f) comparisons of averaged absolute concentrations of $\mathrm{PM}_{1}$ species and gaseous pollutants for each different period.

$\mathrm{O}_{3}$ is an important air pollutant itself and can contribute to the secondary formation of $\mathrm{PM}_{2.5}$. Since the development of effective air pollution control policies must rely on knowledge about the sources, it is important to investigate the major formation processes and emission sources that contribute to the high-PM loadings. Therefore, in this section, we examine how both primary emissions and secondary formation affect PM loadings in Seoul during winter.

Figure 12 shows comparisons of the average concentrations of $\mathrm{PM}_{1}$ components as well as other air pollutants under high- and low-PM loading conditions depicted in Figs. 2 and 3. The average concentrations of all aerosol components and OA sources were 1.7-8.6 times higher during the highloading periods compared to the low-loading periods ( $\mathrm{Ta}-$ ble 3; Fig. 12e, f). A main reason appeared to be meteorological conditions. For example, high-loading periods were generally stagnant with low wind speed $\left(0.99 \pm 0.7 \mathrm{~m} \mathrm{~s}^{-1}\right)$ (Fig. 12a, b), leading to the accumulation of pollutants, especially those mainly from local sources. Indeed, among all species, SV-OOA, HOA, nitrate, and COA showed the highest increases during high-loading periods and their average 
Table 3. Comparison of aerosol properties and meteorological parameters between the high-loading and low-loading periods.

\begin{tabular}{lrr}
\hline & High-PM loading & Low-PM loading \\
\hline $\begin{array}{l}\text { Average nonrefractory submicrometer particulate matter }\left(\mathrm{NR}-\mathrm{PM}_{1}\right) \\
\text { mass concentration }\left(\mu \mathrm{g} \mathrm{m}^{-3}\right)(\text { average } \pm 1 \sigma)\end{array}$ & $43.6 \pm 2.4$ & $12.6 \pm 7.1$ \\
\hline $\mathrm{O} / \mathrm{C}(\mathrm{H} / \mathrm{C})$ ratio & $0.36(1.82)$ & $0.41(1.75)$ \\
\hline Trace gas conc. $\left(\mathrm{CO}(\mathrm{ppm})\right.$ and $\left.\mathrm{NO}_{2} / \mathrm{O}_{3} / \mathrm{SO}_{2}(\mathrm{ppb})\right)$ & $1.2 / 56 / 61 / 7.5$ & $0.5 / 30 / 18.4 / 6.4$ \\
\hline Temperature $\left({ }^{\circ} \mathrm{C}\right)($ average $\pm 1 \sigma)$ & $2.5 \pm 3.4$ & $-2.8 \pm 4.4$ \\
\hline RH $(\%)$ (average $\pm 1 \sigma)$ & $71 \pm 15$ & $50 \pm 12$ \\
\hline * Calculated using the improved Canagaratna ambient method (Canagaratna et al., 2015). & & \\
PM: particulate matter, NR-PM & : nonrefractory submicrometer particulate matter, RH: relative humidity. &
\end{tabular}

enhancement in concentrations was 8.6, 5.2, 4.7, and 4.5 times, respectively, the values during the low-loading periods (Fig. 12e). In addition to accumulating primary pollutants, stable meteorological conditions can also lead to longer atmospheric residence time, which facilitates the local formation of secondary species such as SV-OOA and nitrate. Furthermore, the relatively high RH during the high-loading periods (71\% $\% 15$; Table 3 , Fig. 12a) likely also enhanced the formation of secondary species such as sulfate and LVOOA through aqueous-phase processing. Further evidence for enhanced aqueous-phase processing of secondary aerosol species during high-PM loading periods is shown in Fig. 13; the size distributions of all secondary inorganic species (nitrate, sulfate, and ammonium) were significantly larger during the more polluted periods, peaking at 500-600 nm in $D_{\text {va }}$, compared to the cleaner periods (peaking at 300-400 nm). A previous study in a US city in winter also observed that high RH conditions, and thus enhanced aqueous-phase processing, led to increases in the size modes of sulfate, nitrate, and ammonium (Ge et al., 2012b).

The enhancement ratios of the other primary pollutants, $\mathrm{CO}, \mathrm{SO}_{2}, \mathrm{NO}_{2}, \mathrm{BC}$, and BBOA, were in the range of 1.2-2.5, significantly lower than those of HOA and COA (Fig. 12e). This reflects the fact that they all had bigger contributions from regional sources compared to HOA and COA (Fig. 7). Conversely, average $\mathrm{O}_{3}$ concentration showed a substantial decrease (by $\sim 70 \%$ ) during high aerosol loading periods (Fig. 12e and $\mathrm{f}$ ). In addition to enhanced titration reactions by $\mathrm{NO}_{x}$, another possible reason for $\mathrm{O}_{3}$ decrease was reduced photochemical reactions due to inhibition of light caused by high concentration of PM (He et al., 2014).

The high-loading periods corresponded closely to air masses that are classified as cluster 4 (Fig. 14), which had the shortest trajectories, i.e., slowest wind speeds, as well as the lowest travel height compared to the other three clusters. The air mass in cluster 4 thus likely held larger amounts of pollutants and precursors from the ground. In addition, since air masses in each cluster were expected to pass over regions indicated by the corresponding trajectories, investigating the composition and masses of aerosol in each cluster could shed

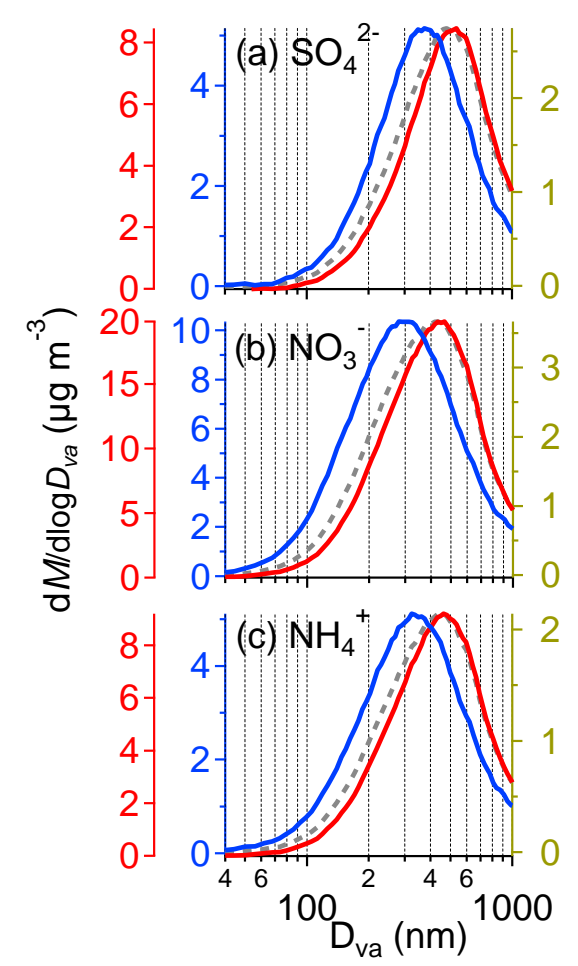

Figure 13. Averaged mass-based size distributions of (a) sulfate, (b) nitrate, and (c) ammonium during the entire (broken grey curve) high-PM (red curve) and low-PM (blue curve) periods as marked in Figs. 2 and 3.

light on how various upwind areas influence air quality at the measurement site. For example, PM in this type of air mass (cluster 4) could also be more oxidized, containing a larger fraction of secondary pollutants due to longer residence time in the atmosphere. Therefore, it would be was composed of a higher fraction of nitrate.

The average aerosol composition during the high-loading periods (Fig. 12) was similar to that for the whole period (Fig. 4), consistent with frequent occurrence of high aerosol pollution episodes, which indicates that these events deter- 


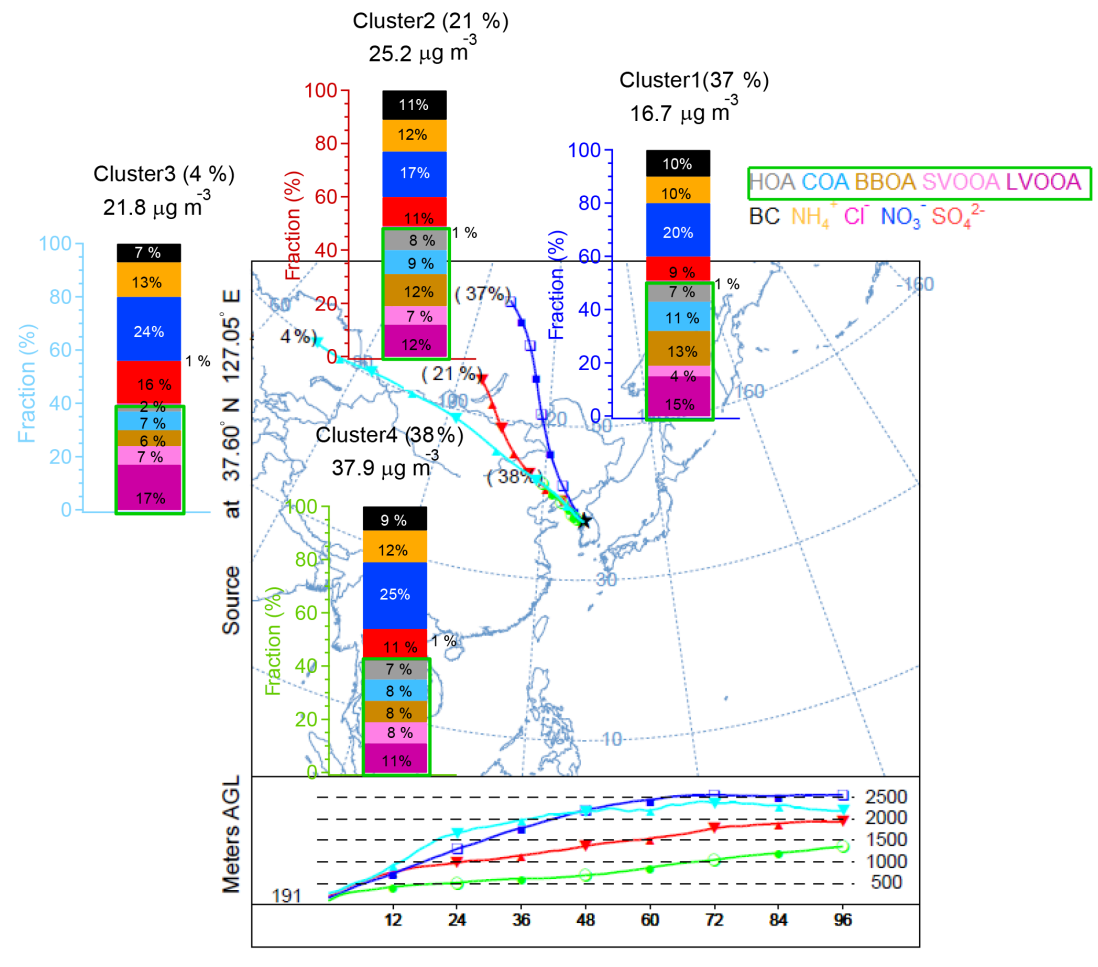

Figure 14. Averaged compositional bar graph of $\mathrm{PM}_{1}$ species (nonrefractory $\mathrm{PM}_{1}$ plus black carbon, $\mathrm{BC}$ ) and each of the $\mathrm{OA}$ factors in different clusters from the four-cluster solution. The trajectories were released at half of the mixing height at the KIST (latitude: $37.60^{\circ} \mathrm{N}$, longitude: $127.05^{\circ} \mathrm{E}$ ) and the average arrival height for the back trajectories for this study was approximately $191 \mathrm{~m}$.

mined the overall characteristics of $\mathrm{PM}_{1}$ in Seoul during winter. Given that local emissions were mostly responsible for these pollution events, controlling the emissions of both primary aerosol particles and precursors for secondary species from local sources might be an effective way to manage air quality in Seoul in winter.

Low-PM loading periods (average $\pm 1 \sigma=12.6 \pm$ $7.1 \mu \mathrm{g} \mathrm{m}^{-3}$ for $\mathrm{PM}_{1}$ ) were commonly associated with high WS $\left(1.8 \pm 1.1 \mathrm{~m} \mathrm{~s}^{-1}\right)$, low RH $(50 \%)$, and long-distance transport of air masses from Russia, Northern China (Inner Mongolia), Mongolia, or North Korea (i.e., Clusters 1, 2, and 3 from back-trajectory analysis; Fig. 14). All three clusters appeared to originate from Russia; however, there were some differences among clusters. For example, Cluster 1 passed over Mongolia and North Korea, whereas Clusters 2 and 3 passed over China. Furthermore, Cluster 3 was composed of the longest trajectories.

Aerosol composition was somewhat different between the high-loading and low- loading periods. Since strong wind could inhibit the accumulation of local primary and secondary species while bringing in pollutants from upwind sources, the mass fractions of species influenced more strongly by local sources, such as nitrate ( 27 vs. $20 \%$ ), SVOOA ( 8 vs. $3 \%$ ), HOA (7 vs. $4 \%$ ), and COA ( 8 vs. $7 \%$ ), were lower during low-loading periods compared to more polluted periods. Conversely, those of regional sources, such as sulfate (10 vs. $12 \%$ ), LV-OOA (10 vs. $20 \%$ ), and BBOA (9 vs. $12 \%$ ), were enhanced (Fig. 12). Although Clusters 1, 2 , and 3 all represented regional transport conditions, PM mass concentrations and compositions were somewhat different because of different origin of air masses. Specifically, Clusters 1 and 2 were almost directly to the north, whereas Cluster 3 was more towards the west (Fig. 14). In comparison, Clusters 1 and 2 had higher fractions of BBOA but lower fractions of LV-OOA and sulfate. A possible explanation for this observation is that the northwestern area might have more anthropogenic sources than the northern area does.

As shown in Fig. 2, PM concentration often changed abruptly with the appearance and dissipation of a high-PM $\mathrm{PM}_{1}$ event occurring rather quickly (within several hours). The changes were commonly associated with changes in meteorological conditions, especially wind direction and speed. Similar trends of sudden changes in air quality have also been observed in other studies in China and have been attributed to meteorology (Zhang et al., 2015). For these reasons, it appears that regional meteorology played an important role in causing high-PM pollution conditions in Seoul. 


\section{Conclusions}

Aerosol composition, size distribution, sources, and evolution processes were investigated using an HR-ToF-AMS and an SMPS in Seoul, Korea, during winter 2015. The average $\mathrm{PM}_{1}$ concentration was $27.5 \mu \mathrm{g} \mathrm{m}^{-3}$ and the total mass was dominated by organics $(44 \%)$, followed by nitrate $(24 \%)$ and sulfate $(10 \%)$. Secondary materials (i.e., $\mathrm{NO}_{3}^{-}, \mathrm{SO}_{4}^{2-}$, $\mathrm{NH}_{4}^{+}, \mathrm{SV}-\mathrm{OOA}$, and LV-OOA) together accounted for $64 \%$ of the $\mathrm{PM}_{1}$ total mass, with the remainder being primary materials (HOA, COA, BBOA, and BC). Cooking, fossil fuel combustion, and wood combustion were identified as major POA sources in Seoul, contributing an average of $59 \%$ to total OA mass during this study.

Meteorological conditions and various emission sources influenced the concentrations, compositions, size distributions, and properties of aerosol particles in Seoul. High-PM pollution periods tended to build up over a period of 4-5 days and were interleaved with multiple days that were relatively clean. High-aerosol-loading periods were commonly found under relatively stagnant conditions, with low wind speed and aerosol from these periods characterized by enhanced fractional contributions of nitrate $(27 \%)$ and SV-OOA ( $8 \%)$, indicating a strong influence from local production of secondary aerosol. In contrast, under relatively dynamic meteorological conditions with higher wind speed, aerosol loading was generally low and $\mathrm{PM}_{1}$ contained larger fractions of species with regional sources such as sulfate $(12 \%)$, LVOOA (20\%), and BBOA (12\%). The average $\mathrm{O} / \mathrm{C}$ ratio of OA was also higher during low-loading periods ( 0.41 vs. 0.35 for high-loading periods), indicating the influence of moreoxidized OA likely from long-range transport.

Total POA concentration was 3 times as enhanced during high-loading periods. In addition, an enhancement of the fractional contributions of BBOA from the high-loading periods $(9 \%)$ was observed during low-loading periods $(12 \%)$. In this study, we found that nearly half of the OA mass was $\mathrm{POA}$ and that PAHs in $\mathrm{PM}_{1}$ were mainly from biomass burning $(r=0.90)$. These results suggest that it is important to reduce emissions from combustion sources to improve air quality and protect public health in Seoul in winter. Together, local formation of secondary species (e.g., Nitrate, SV-OOA) during stable meteorological conditions was also significant for high-PM loadings. Thus, the serious pollution observed in Seoul during winter was caused by a combination of factors, including meteorological conditions, emissions from local primary sources, secondary formation, as well as transport of air masses from upwind locations and other unknown factors.

\section{Data availability}

The hourly ambient temperature, RH, WS and WD data were acquired from the Korea Meteorological Administra- tion (http://www.kma.go.kr). The hourly trace gas data (e.g., $\mathrm{CO}, \mathrm{SO}_{2}, \mathrm{O}_{3}$ and $\mathrm{NO}_{2}$ concentrations) were acquired from the Korea Environment Corporation (K eco) (http://www. airkorea.or.kr). Raw data are archived at the Korea Institute of Science and Technology and are available on request.

Competing interests. The authors declare that they have no conflict of interest.

\section{The Supplement related to this article is available online at doi:10.5194/acp-17-2009-2017-supplement.}

Acknowledgements. This work was supported by the Korea Institute of Science and Technology (KIST). Qi Zhang acknowledges the Changjiang Scholars program of the Chinese Ministry of Education.

Edited by: V.-M. Kerminen

Reviewed by: three anonymous referees

\section{References}

Adhikary, B., Carmichael, G. R., Kulkarni, S., Wei, C., Tang, Y., D’Allura, A., Mena-Carrasco, M., Streets, D. G., Zhang, Q., Pierce, R. B., Al-Saadi, J. A., Emmons, L. K., Pfister, G. G., Avery, M. A., Barrick, J. D., Blake, D. R., Brune, W. H., Cohen, R. C., Dibb, J. E., Fried, A., Heikes, B. G., Huey, L. G., O'Sullivan, D. W., Sachse, G. W., Shetter, R. E., Singh, H. B., Campos, T. L., Cantrell, C. A., Flocke, F. M., Dunlea, E. J., Jimenez, J. L., Weinheimer, A. J., Crounse, J. D., Wennberg, P. O., Schauer, J. J., Stone, E. A., Jaffe, D. A., and Reidmiller, D. R.: A regional scale modeling analysis of aerosol and trace gas distributions over the eastern Pacific during the INTEX-B field campaign, Atmos. Chem. Phys., 10, 2091-2115, doi:10.5194/acp-10-2091-2010, 2010.

Aiken, A. C., Decarlo, P. F., Kroll, J. H., Worsnop, D. R., Huffman, J. A., Docherty, K. S., Ulbrich, I. M., Mohr, C., Kimmel, J. R., Sueper, D., Sun, Y., Zhang, Q., Trimborn, A., Northway, M., Ziemann, P. J., Canagaratna, M. R., Onasch, T. B., Alfarra, M. R., Prevot, A. S. H., Dommen, J., Duplissy, J., Metzger, A., Baltensperger, U., and Jimenez, J. L.: O/C and OM/OC ratios of primary, secondary, and ambient organic aerosols with highresolution time-of-flight aerosol mass spectrometry, Environ. Sci. Technol., 42, 4478-4485, doi:10.1021/es703009q, 2008.

Aiken, A. C., Salcedo, D., Cubison, M. J., Huffman, J. A., DeCarlo, P. F., Ulbrich, I. M., Docherty, K. S., Sueper, D., Kimmel, J. R., Worsnop, D. R., Trimborn, A., Northway, M., Stone, E. A., Schauer, J. J., Volkamer, R. M., Fortner, E., de Foy, B., Wang, J., Laskin, A., Shutthanandan, V., Zheng, J., Zhang, R., Gaffney, J., Marley, N. A., Paredes-Miranda, G., Arnott, W. P., Molina, L. T., Sosa, G., and Jimenez, J. L.: Mexico City aerosol analysis during MILAGRO using high resolution aerosol mass spectrometry at the urban supersite (T0) - Part 1: Fine particle 
composition and organic source apportionment, Atmos. Chem. Phys., 9, 6633-6653, doi:10.5194/acp-9-6633-2009, 2009.

Alfarra, M. R., Coe, H., Allan, J. D., Bower, K. N., Boudries, H., Canagaratna, M. R., Jimenez, J. L., Jayne, J. T., Garforth, A., Li, S.-M., and Worsnop, D. R.: Characterization of urban and ruralorganic particulate in the Lower Fraser Valley using two Aerodyne Aerosol Mass Spectrometers, Atmos. Environ., 38, 57455758, doi:10.1016/j.atmosenv.2004.01.054, 2004.

Alfarra, M. R., Prevot, A. S. H., Szidat, S., Sandradewi, J., Weimer, S., Lanz, V. A., Schreiber, D., Mohr, M., and Baltensperger, U.: Identification of the Mass Spectral Signature of Organic Aerosols from Wood Burning Emissions, Environ. Sci. Technol., 41, 5770-5777, doi:10.1021/es062289b, 2007

Allan, J. D., Alfarra, M. R., Bower, K. N., Williams, P. I., Gallagher, M. W., Jimenez, J. L., McDonald, A. G., Nemitz, E., Canagaratna, M. R., Jayne, J. T., Coe, H., and Worsnop, D. R.: Quantitative sampling using an Aerodyne aerosol mass spectrometer 2. Measurements of fine particulate chemical composition in two U.K. cities, J. Geophys. Res., 108, 4091, doi:10.1029/2002JD002359, 2003.

Allan, J. D., Delia, A. E., Coe, H., Bower, K. N., Alfarra, M. R., Jimenez, J. L., Middlebrook, A. M., Drewnick, F., Onasch, T. B., Canagaratna, M. R., Jayne, J. T., and Worsnop, D. R.: A generalised method for the extraction of chemically resolved mass spectra from aerodyne aerosol mass spectrometer data, J. Aerosol. Sci., 35, 909-922, doi:10.1016/j.jaerosci.2004.02.007, 2004.

Brown, S. G., Roberts, P. T., McCarthy, M. C., Lurmann, F. W., and Hyslop, N. P.: Wintertime vertical variations in particulate matter (PM) and precursor concentrations in the San Joaquin Valley during the California Regional coarse PM/fine PM Air Quality Study, J. Air Waste Ma., 56, 1267-1277, 2006.

Budisulistiorini, S. H., Li, X., Bairai, S. T., Renfro, J., Liu, Y., Liu, Y. J., McKinney, K. A., Martin, S. T., McNeill, V. F., Pye, H. O. T., Nenes, A., Neff, M. E., Stone, E. A., Mueller, S., Knote, C., Shaw, S. L., Zhang, Z., Gold, A., and Surratt, J. D.: Examining the effects of anthropogenic emissions on isoprenederived secondary organic aerosol formation during the 2013 Southern Oxidant and Aerosol Study (SOAS) at the Look Rock, Tennessee ground site, Atmos. Chem. Phys., 15, 8871-8888, doi:10.5194/acp-15-8871-2015, 2015.

Canagaratna, M. R., Jayne, J. T., Jimenez, J. L., Allan, J. D., Alfarra, M. R., Zhang, Q., Onasch, T. B., Drewnick, F., Coe, H., Middlebrook, A., Delia, A., Williams, L. R., Trimborn, A. M., Northway, M. J., DeCarlo, P. F., Kolb, C. E., Davidovits, P., and Worsnop, D. R.: Chemical and microphysical characterization of ambient aerosols with the aerodyne aerosol mass spectrometer, Mass Spectrom. Rev., 26, 185-222, doi:10.1002/mas.20115, 2007.

Canagaratna, M. R., Jimenez, J. L., Kroll, J. H., Chen, Q., Kessler, S. H., Massoli, P., Hildebrandt Ruiz, L., Fortner, E., Williams, L. R., Wilson, K. R., Surratt, J. D., Donahue, N. M., Jayne, J. T., and Worsnop, D. R.: Elemental ratio measurements of organic compounds using aerosol mass spectrometry: characterization, improved calibration, and implications, Atmos. Chem. Phys., 15, 253-272, doi:10.5194/acp-15-253-2015, 2015.

Cao, J.-j., Wang, Q.-y., Chow, J. C., Watson, J. G., Tie, X.-x., Shen, Z.-x., Wang, P., and An, Z.-s.: Impacts of aerosol compositions on visibility impairment in Xi'an, China, Atmos. Environ., 59, 559-566, doi:10.1016/j.atmosenv.2012.05.036, 2012.

Choi, J.-K., Heo, J.-B., Ban, S.-J., Yi, S.-M., and Zoh, K.-D.: Chemical characteristics of $\mathrm{PM}_{2.5}$ aerosol in Incheon, Korea, Atmos. Environ., 60, 583-592, 2012.

Choi, N. R., Lee, S. P., Lee, J. Y., Jung, C. H., and Kim, Y. P.: Speciation and source identification of organic compounds in $\mathrm{PM}_{10}$ over Seoul, South Korea, Chemosphere, 144, 1589-1596, doi:10.1016/j.chemosphere.2015.10.041, 2016.

Crippa, M., DeCarlo, P. F., Slowik, J. G., Mohr, C., Heringa, M. F., Chirico, R., Poulain, L., Freutel, F., Sciare, J., Cozic, J., Di Marco, C. F., Elsasser, M., Nicolas, J. B., Marchand, N., Abidi, E., Wiedensohler, A., Drewnick, F., Schneider, J., Borrmann, S., Nemitz, E., Zimmermann, R., Jaffrezo, J.-L., Prévôt, A. S. H., and Baltensperger, U.: Wintertime aerosol chemical composition and source apportionment of the organic fraction in the metropolitan area of Paris, Atmos. Chem. Phys., 13, 961-981, doi:10.5194/acp-13-961-2013, 2013.

Cubison, M. J., Ortega, A. M., Hayes, P. L., Farmer, D. K., Day, D., Lechner, M. J., Brune, W. H., Apel, E., Diskin, G. S., Fisher, J. A., Fuelberg, H. E., Hecobian, A., Knapp, D. J., Mikoviny, T., Riemer, D., Sachse, G. W., Sessions, W., Weber, R. J., Weinheimer, A. J., Wisthaler, A., and Jimenez, J. L.: Effects of aging on organic aerosol from open biomass burning smoke in aircraft and laboratory studies, Atmos. Chem. Phys., 11, 12049-12064, doi:10.5194/acp-11-12049-2011, 2011.

Dall'Osto, M., Ovadnevaite, J., Ceburnis, D., Martin, D., Healy, R. M., O’Connor, I. P., Kourtchev, I., Sodeau, J. R., Wenger, J. C., and O'Dowd, C.: Characterization of urban aerosol in Cork city (Ireland) using aerosol mass spectrometry, Atmos. Chem. Phys., 13, 4997-5015, doi:10.5194/acp-13-4997-2013, 2013.

DeCarlo, P. F., Slowik, J. G., Worsnop, D. R., Davidovits, P., and Jimenez, J. L.: Particle morphology and density characterization by combined mobility and aerodynamic diameter measurements. Part 1: Theory, Aerosol Sci. Tech., 38, 1185-1205, doi:10.1080/02786820590928897, 2004.

DeCarlo, P. F., Kimmel, J. R., Trimborn, A., Northway, M. J., Jayne, J. T., Aiken, A. C., Gonin, M., Fuhrer, K., Horvath, T., Docherty, K. S., Worsnop, D. R., and Jimenez, J. L.: Field-deployable, high-resolution, time-of-flight aerosol mass spectrometer, Anal. Chem., 78, 8281-8289, doi:10.1021/ac061249n, 2006.

Ding, A. J., Fu, C. B., Yang, X. Q., Sun, J. N., Zheng, L. F., Xie, Y. N., Herrmann, E., Nie, W., Petäjä, T., Kerminen, V.-M., and Kulmala, M.: Ozone and fine particle in the western Yangtze River Delta: an overview of $1 \mathrm{yr}$ data at the SORPES station, Atmos. Chem. Phys., 13, 5813-5830, doi:10.5194/acp-13-58132013, 2013.

Ding, A. J., Huang, X., Nie, W., Sun, J. N., Kerminen, V. M., Petäjä, T., Su, H., Cheng, Y. F., Yang, X. Q., Wang, M. H., Chi, X. G., Wang, J. P., Virkkula, A., Guo, W. D., Yuan, J., Wang, S. Y., Zhang, R. J., Wu, Y. F., Song, Y., Zhu, T., Zilitinkevich, S., Kulmala, M., and Fu, C. B.: Enhanced haze pollution by black carbon in megacities in China, Geophys. Res. Lett., 43, 2873-2879, doi:10.1002/2016g1067745, 2016.

Draxler, R. R. and Hess, G. D.: Description of the HYSPLIT_4 modeling system, NOAA Air Resources Laboratory, Silver Spring, Maryland, USA, available at: http://www.arl.noaa.gov/ documents/reports/arl-224.pdf, last access: 5 January 2014, 1997. 
Draxler, R. R., Stunder, B., Rolph, G., Stein, A., and Taylor, A.: HYSPLIT_4 User's Guide, NOAA Air Resources Laboratory, Silver Spring, Maryland, USA, available at: http://www.arl. noaa.gov/documents/reports/hysplit_user_guide.pdf, last access: 1 June 2015, 2012.

Drewnick, F., Jayne, J. T., Canagaratna, M., Worsnop, D. R., and Demerjian, K. L.: Measurement of ambient aerosol composition during the PMTACS-NY 2001 using an aerosol mass spectrometer. Part II: Chemically speciated mass distributions, Aerosol Sci. Technol., 38, 104-117, doi:10.1080/02786820390229534, 2004.

Dzepina, K., Arey, J., Marr, L. C., Worsnop, D. R., Salcedo, D., Zhang, Q., Onasch, T. B., Molina, L. T., Molina, M. J., and Jimenez, J. L.: Detection of particle-phase polycyclic aromatic hydrocarbons in Mexico City using an aerosol mass spectrometer, Int. J. Mass Spectrom., 263, 152-170, doi:10.1016/j.ijms.2007.01.010, 2007.

Ervens, B., Turpin, B. J., and Weber, R. J.: Secondary organic aerosol formation in cloud droplets and aqueous particles (aqSOA): a review of laboratory, field and model studies, Atmos. Chem. Phys., 11, 11069-11102, doi:10.5194/acp-1111069-2011, 2011.

Ge, X. L., Setyan, A., Sun, Y., and Zhang, Q.: Primary and secondary organic aerosols in Fresno, California during wintertime: Results from high resolution aerosol mass spectrometry, J. Geophys. Res., 117, D19301, doi:10.1029/2012JD018026, 2012a.

Ge, X. L., Zhang, Q., Sun, Y. L., Ruehl, C. R., and Setyan, A.: Effect of aqueous-phase processing on aerosol chemistry and size distributions in Fresno, California, during wintertime, Environ. Chem., 9, 221-235, doi:10.1071/en11168, 2012b.

Gelencsér, A., May, B., Simpson, D., Sánchez-Ochoa, A., Kasper-Giebl, A., Puxbaum, H., Caseiro, A., Pio, C., and Legrand, M.: Source apportionment of PM2.5 organic aerosol over Europe: Primary/secondary, natural/anthropogenic, and fossil/biogenic origin, J. Geophys. Res., 112, D23S04, doi:10.1029/2006JD008094, 2007.

Guo, S., Hu, M., Zamora, M. L., Peng, J., Shang, D., Zheng, J., Du, Z., Wu, Z., Shao, M., Zeng, L., Molina, M. J., and Zhang, R.: Elucidating severe urban haze formation in China, P. Natl. Acad. Sci. USA, 111, 17373-17378, doi:10.1073/pnas.1419604111, 2014.

Hannigan, M. P., Cass, G. R., Penman, B. W., Crespi, C. L., Lafleur, A. L., Busby, W. F., Thilly, W. G., and Simoneit, B. R. T.: Bioassay-Directed Chemical Analysis of Los Angeles Airborne Particulate Matter Using a Human Cell Mutagenicity Assay, Environ. Sci. Technol., 32, 3502-3514, doi:10.1021/es9706561, 1998.

Harrison, R. M. and Yin, J.: Particulate matter in the atmosphere: which particle properties are important for its effects on health?, Sci. Total Environ., 249, 85-101, doi:10.1016/S00489697(99)00513-6, 2000

Hayes, P. L., Ortega, A. M., Cubison, M. J., Froyd, K. D., Zhao, Y., Cliff, S. S., Hu, W. W., Toohey, D. W., Flynn, J. H., Lefer, B. L., Grossberg, N., Alvarez, S., Rappenglueck, B., Taylor, J. W., Allan, J. D., Holloway, J. S., Gilman, J. B., Kuster, W. C., De Gouw, J. A., Massoli, P., Zhang, X., Liu, J., Weber, R. J., Corrigan, A. L., Russell, L. M., Isaacman, G., Worton, D. R., Kreisberg, N. M., Goldstein, A. H., Thalman, R., Waxman, E. M., Volkamer, R., Lin, Y. H., Surratt, J. D., Kleindienst, T. E., Offenberg, J. H., Dusanter, S., Griffith, S., Stevens, P. S., Brioude, J., Angevine, W. M., and Jimenez, J. L.: Organic aerosol com- position and sources in Pasadena, California, during the 2010 CalNex campaign, J. Geophys. Res.-Atmos., 118, 9233-9257, doi:10.1002/jgrd.50530, 2013.

He, H., Wang, Y. S., Ma, Q. X., Ma, J. Z., Chu, B. W., Ji, D. S., Tang, G. Q., Liu, C., Zhang, H. X., and Hao, J. M.: Mineral dust and $\mathrm{NO}_{\mathrm{x}}$ promote the conversion of $\mathrm{SO}_{2}$ to sulfate in heavy pollution days, Scientific Reports, 4, 4172, doi:10.1038/srep04172, 2014.

He, J., Zielinska, B., and Balasubramanian, R.: Composition of semi-volatile organic compounds in the urban atmosphere of Singapore: influence of biomass burning, Atmos. Chem. Phys., 10, 11401-11413, doi:10.5194/acp-10-11401-2010, 2010.

He, L.-Y., Hu, M., Huang, X. F., Yu, B. D., Zhang, Y. H., and Liu, D. Q.: Measurement of emissions of fine particulate organic matter from Chinese cooking, Atmos. Environ., 38, 6557-6564, doi:10.1016/j.atmosenv.2004.08.034, 2004.

He, L.-Y., Huang, X.-F., Xue, L., Hu, M., Lin, Y., Zheng, J., Zhang, R., and Zhang, Y.-H.: Submicron aerosol analysis and organic source apportionment in an urban atmosphere in Pearl River Delta of China using high-resolution aerosol mass spectrometry, J. Geophys. Res., 116, D12304, doi:10.1029/2010jd014566, 2011.

Hennigan, C. J., Bergin, M. H., Russell, A. G., Nenes, A., and Weber, R. J.: Gas/particle partitioning of water-soluble organic aerosol in Atlanta, Atmos. Chem. Phys., 9, 3613-3628, doi:10.5194/acp-9-3613-2009, 2009.

Heo, J.-B., Hopke, P. K., and Yi, S.-M.: Source apportionment of $\mathrm{PM}_{2.5}$ in Seoul, Korea, Atmos. Chem. Phys., 9, 4957-4971, doi:10.5194/acp-9-4957-2009, 2009.

Huang, R.-J., Zhang, Y., Bozzetti, C., Ho, K.-F., Cao, J.-J., Han, Y., Daellenbach, K. R., Slowik, J. G., Platt, S. M., Canonaco, F., Zotter, P., Wolf, R., Pieber, S. M., Bruns, E. A., Crippa, M., Ciarelli, G., Piazzalunga, A., Schwikowski, M., Abbaszade, G., SchnelleKreis, J., Zimmermann, R., An, Z., Szidat, S., Baltensperger, U., El Haddad, I., and Prévôt, A. S. H.: High secondary aerosol contribution to particulate pollution during haze events in China, Nature, 514, 218-222, doi:10.1038/nature13774, 2014.

Huang, X.-F., He, L.-Y., Hu, M., Canagaratna, M. R., Sun, Y., Zhang, Q., Zhu, T., Xue, L., Zeng, L.-W., Liu, X.-G., Zhang, Y.-H., Jayne, J. T., Ng, N. L., and Worsnop, D. R.: Highly time-resolved chemical characterization of atmospheric submicron particles during 2008 Beijing Olympic Games using an Aerodyne High-Resolution Aerosol Mass Spectrometer, Atmos. Chem. Phys., 10, 8933-8945, doi:10.5194/acp-10-8933-2010, 2010.

Huang, X.-F., He, L.-Y., Hu, M., Canagaratna, M. R., Kroll, J. H., Ng, N. L., Zhang, Y.-H., Lin, Y., Xue, L., Sun, T.-L., Liu, X.-G., Shao, M., Jayne, J. T., and Worsnop, D. R.: Characterization of submicron aerosols at a rural site in Pearl River Delta of China using an Aerodyne High-Resolution Aerosol Mass Spectrometer, Atmos. Chem. Phys., 11, 1865-1877, doi:10.5194/acp-11-18652011, 2011.

Huang, X.-F., He, L.-Y., Xue, L., Sun, T.-L., Zeng, L.-W., Gong, Z.-H., Hu, M., and Zhu, T.: Highly time-resolved chemical characterization of atmospheric fine particles during 2010 Shanghai World Expo, Atmos. Chem. Phys., 12, 4897-4907, doi:10.5194/acp-12-4897-2012, 2012.

IPCC: Summary for policymakers, in: Climate Change 2013: The Physical Science Basis. Contribution of Working Group 1 to the Fifth Assessment Report of the Intergovernmental Panel on Cli- 
mate Change, edited by: Stocker, T. F., Qin, D., Plattner, G.-K., Tignor, M., Allen, S. K., Boschung, J., Nauels, A., Xia, Y., Bex, V., and Midgley, P. M., Cambridge University Press, Cambridge, UK, New York, NY, USA, 3-29, 2013.

Jiang, Q., Sun, Y. L., Wang, Z., and Yin, Y.: Aerosol composition and sources during the Chinese Spring Festival: fireworks, secondary aerosol, and holiday effects, Atmos. Chem. Phys., 15, 6023-6034, doi:10.5194/acp-15-6023-2015, 2015.

Jimenez, J. L., Canagaratna, M. R., Donahue, N. M., Prevot, A. S. H., Zhang, Q., Kroll, J. H., DeCarlo, P. F., Allan, J. D., Coe, H., Ng, N. L., Aiken, A. C., Docherty, K. S., Ulbrich, I. M., Grieshop, A. P., Robinson, A. L., Duplissy, J., Smith, J. D., Wilson, K. R., Lanz, V. A., Hueglin, C., Sun, Y. L., Tian, J., Laaksonen, A., Raatikainen, T., Rautiainen, J., Vaattovaara, P., Ehn, M., Kulmala, M., Tomlinson, J. M., Collins, D. R., Cubison, M. J., Dunlea, E. J., Huffman, J. A., Onasch, T. B., Alfarra, M. R., Williams, P. I., Bower, K., Kondo, Y., Schneider, J., Drewnick, F., Borrmann, S., Weimer, S., Demerjian, K., Salcedo, D., Cottrell, L., Griffin, R., Takami, A., Miyoshi, T., Hatakeyama, S., Shimono, A., Sun, J. Y., Zhang, Y. M., Dzepina, K., Kimmel, J. R., Sueper, D., Jayne, J. T., Herndon, S. C., Trimborn, A. M., Williams, L. R., Wood, E. C., Middlebrook, A. M., Kolb, C. E., Baltensperger, U., and Worsnop, D. R.: Evolution of Organic Aerosols in the Atmosphere, Science, 326, 1525-1529, doi:10.1126/science.1180353, 2009.

Jung, J., Lyu, Y., Lee, M., Hwang, T., Lee, S., and Oh, S.: Impact of Siberian forest fires on the atmosphere over the Korean Peninsula during summer 2014, Atmos. Chem. Phys., 16, 6757-6770, doi:10.5194/acp-16-6757-2016, 2016.

Kaneyasu, N., Ohta, S., and Murao, N.: Seasonal variation in the chemical composition of atmospheric aerosols and gaseous species in Sapporo, Japan, Atmos. Environ., 29, 1559-1568, doi:10.1016/1352-2310(94)00356-p, 1995.

Kang, S. H., Heo, J., Oh, I. Y., Kim, J., Lim, W. H., Cho, Y., Choi, E. K., Yi, S. M., Do Shin, S., Kim, H., and Oh, S.: Ambient air pollution and out-of-hospital cardiac arrest, Int. J. Cardiol., 203, 1086-1092, doi:10.1016/j.ijcard.2015.11.100, 2016.

Kim, E., Hopke, P. K., and Edgerton, E. S.: Source identification of Atlanta aerosol by positive matrix factorization, J. Air Waste Ma., 53, 731-739, doi:10.1080/10473289.2003.10466209, 2003.

Kim, Y., Yoon, S. C., Kim, S. W., Kim, K. Y., Lim, H. C., and Ryu, J.: Observation of new particle formation and growth events in Asian continental outflow, Atmos. Environ., 64, 160-168, doi:10.1016/j.atmosenv.2012.09.057, 2013.

Kim, Y., Kim, S.-W., Yoon, S.-C., Kim, M.-H., and Park, K.-H.: Aerosol properties and associated regional meteorology during winter pollution event at Gosan climate observatory, Korea, Atmos. Environ., 85, 9-17, doi:10.1016/j.atmosenv.2013.11.041, 2014.

KOSAE: Studies of Measures for Improving/Complementing the Master Plan for the Metropolitan Air Quality Management, Report, KOSAE (Korean Society for Atmospheric Environment), Gwacheon, Korea, 2009 (in Korean).

Kulmala, M., Lappalainen, H. K., Petäjä, T., Kurten, T., Kerminen, V.-M., Viisanen, Y., Hari, P., Sorvari, S., Bäck, J., Bondur, V., Kasimov, N., Kotlyakov, V., Matvienko, G., Baklanov, A., Guo, H. D., Ding, A., Hansson, H.-C., and Zilitinkevich, S.: Introduction: The Pan-Eurasian Experiment (PEEX) multidisciplinary, multiscale and multicomponent research and capacity-building initiative, Atmos. Chem. Phys., 15, 1308513096, doi:10.5194/acp-15-13085-2015, 2015.

Kuwata, M., Zorn, S. R., and Martin, S. T.: Using Elemental Ratios to Predict the Density of Organic Material Composed of Carbon, Hydrogen, and Oxygen, Environ. Sci. Technol., 46, 787794, doi:10.1021/es202525q, 2012.

Lanz, V. A., Alfarra, M. R., Baltensperger, U., Buchmann, B., Hueglin, C., and Prévôt, A. S. H.: Source apportionment of submicron organic aerosols at an urban site by factor analytical modelling of aerosol mass spectra, Atmos. Chem. Phys., 7, 15031522, doi:10.5194/acp-7-1503-2007, 2007.

Lanz, V. A., Alfarra, M. R., Baltensperger, U., Buchmann, B., Hueglin, C., Szidat, S., Wehrli, M. N., Wacker, L., Weimer, S., Caseiro, A., Puxbaum, H., and Prevot, A. S. H.: Source Attribution of Submicron Organic Aerosols during Wintertime Inversions by Advanced Factor Analysis of Aerosol Mass Spectra, Environ. Sci. Technol., 42, 214-220, doi:10.1021/es0707207, 2008.

Li, Y. J., Lee, B. P., Su, L., Fung, J. C. H., and Chan, C. K.: Seasonal characteristics of fine particulate matter (PM) based on highresolution time-of-flight aerosol mass spectrometric (HR-ToFAMS) measurements at the HKUST Supersite in Hong Kong, Atmos. Chem. Phys., 15, 37-53, doi:10.5194/acp-15-37-2015, 2015.

Lim, S., Lee, M., Lee, G., Kim, S., Yoon, S., and Kang, K.: Ionic and carbonaceous compositions of $\mathrm{PM}_{10}, \mathrm{PM}_{2.5}$ and $\mathrm{PM}_{1.0}$ at Gosan ABC Superstation and their ratios as source signature, Atmos. Chem. Phys., 12, 2007-2024, doi:10.5194/acp-12-20072012, 2012.

Liu, X. G., Li, J., Qu, Y., Han, T., Hou, L., Gu, J., Chen, C., Yang, Y., Liu, X., Yang, T., Zhang, Y., Tian, H., and Hu, M.: Formation and evolution mechanism of regional haze: a case study in the megacity Beijing, China, Atmos. Chem. Phys., 13, 4501-4514, doi:10.5194/acp-13-4501-2013, 2013.

Lurmann, F. W., Brown, S. G., McCarthy, M. C., and Roberts, P. T.: Processes Influencing Secondary Aerosol Formation in the San Joaquin Valley during Winter, J. Air Waste Ma., 56, 1679-1693, 2006.

Marr, L. C., Dzepina, K., Jimenez, J. L., Reisen, F., Bethel, H. L., Arey, J., Gaffney, J. S., Marley, N. A., Molina, L. T., and Molina, M. J.: Sources and transformations of particle-bound polycyclic aromatic hydrocarbons in Mexico City, Atmos. Chem. Phys., 6, 1733-1745, doi:10.5194/acp-6-1733-2006, 2006.

Middlebrook, A. M., Bahreini, R., Jimenez, J. L., and Canagaratna, M. R.: Evaluation of Composition-Dependent Collection Efficiencies for the Aerodyne Aerosol Mass Spectrometer using Field Data, Aerosol Sci. Tech., 46, 258-271, doi:10.1080/02786826.2011.620041, 2012.

Mohr, C., Huffman, J. A., Cubison, M. J., Aiken, A. C., Docherty, K. S., Kimmel, J. R., Ulbrich, I. M., Hannigan, M., and Jimenez, J. L.: Characterization of Primary Organic Aerosol Emissions from Meat Cooking, Trash Burning, and Motor Vehicles with High-Resolution Aerosol Mass Spectrometry and Comparison with Ambient and Chamber Observations, Environ. Sci. Technol., 43, 2443-2449, doi:10.1021/es8011518, 2009.

Mohr, C., DeCarlo, P. F., Heringa, M. F., Chirico, R., Slowik, J. G., Richter, R., Reche, C., Alastuey, A., Querol, X., Seco, R., Peñuelas, J., Jiménez, J. L., Crippa, M., Zimmermann, R., Baltensperger, U., and Prévôt, A. S. H.: Identification and quantification of organic aerosol from cooking and other sources in 
Barcelona using aerosol mass spectrometer data, Atmos. Chem. Phys., 12, 1649-1665, doi:10.5194/acp-12-1649-2012, 2012.

Morgan, W. T., Allan, J. D., Bower, K. N., Highwood, E. J., Liu, D., McMeeking, G. R., Northway, M. J., Williams, P. I., Krejci, R., and Coe, H.: Airborne measurements of the spatial distribution of aerosol chemical composition across Europe and evolution of the organic fraction, Atmos. Chem. Phys., 10, 4065-4083, doi:10.5194/acp-10-4065-2010, 2010.

Ng, N. L., Canagaratna, M. R., Zhang, Q., Jimenez, J. L., Tian, J., Ulbrich, I. M., Kroll, J. H., Docherty, K. S., Chhabra, P. S., Bahreini, R., Murphy, S. M., Seinfeld, J. H., Hildebrandt, L., Donahue, N. M., DeCarlo, P. F., Lanz, V. A., Prévôt, A. S. H., Dinar, E., Rudich, Y., and Worsnop, D. R.: Organic aerosol components observed in Northern Hemispheric datasets from Aerosol Mass Spectrometry, Atmos. Chem. Phys., 10, 46254641, doi:10.5194/acp-10-4625-2010, 2010.

Ng, N. L., Canagaratna, M. R., Jimenez, J. L., Zhang, Q., Ulbrich, I. M., and Worsnop, D. R.: Real-Time Methods for Estimating Organic Component Mass Concentrations from Aerosol Mass Spectrometer Data, Environ. Sci. Technol., 45, 910-916, doi:10.1021/es102951k, 2011.

NIER: Annual report of air quality in Korea 2013, National Institute of Environmental Reasearch, NIER-GP2014157, available at: http://webbook.me.go.kr/DLi-File/NIER/09/ 019/5584427.pdf, last access: 21 January 2016, 2014.

Paatero, P. and Tapper, U.: Positive matrix factorization A nonnegative factor model with optimal utilization of error-Estimates of data values, Environmetrics, 5, 111-126, doi:10.1002/env.3170050203, 1994.

Parworth, C., Fast, J., Mei, F., Shippert, T., Sivaraman, C., Tilp, A., Watson, T., and Zhang, Q.: Long-term measurements of submicrometer aerosol chemistry at the southern great plains (SPG) using an aerosol chemical speciation monitor (ACSM), Atmos. Environ., 106, 12, doi:10.1016/j.atmosenv.2015.01.060, 2015.

Petäjä, T., Jarvi, L., Kerminen, V. M., Ding, A. J., Sun, J. N., Nie, W., Kujansuu, J., Virkkula, A., Yang, X. Q., Fu, C. B., Zilitinkevich, S., and Kulmala, M.: Enhanced air pollution via aerosolboundary layer feedback in China, Scientific Reports, 6, 18998, doi:10.1038/srep18998, 2016.

Pope III, C. A. and Dockery, D. W.: Health Effects of Fine Particulate Air Pollution: Lines that Connect, J. Air Waste Ma., 56, 709-742, 2006.

Pöschl, U.: Atmospheric Aerosols: Composition, Transformation, Climate and Health Effects, Angew. Chem. Int. Edit., 44, 75207540, doi:10.1002/anie.200501122, 2005.

Quan, J., Zhang, Q., He, H., Liu, J., Huang, M., and Jin, H.: Analysis of the formation of fog and haze in North China Plain (NCP), Atmos. Chem. Phys., 11, 8205-8214, doi:10.5194/acp-11-82052011, 2011.

Salcedo, D., Onasch, T. B., Dzepina, K., Canagaratna, M. R., Zhang, Q., Huffman, J. A., DeCarlo, P. F., Jayne, J. T., Mortimer, P., Worsnop, D. R., Kolb, C. E., Johnson, K. S., Zuberi, B., Marr, L. C., Volkamer, R., Molina, L. T., Molina, M. J., Cardenas, B., Bernabé, R. M., Márquez, C., Gaffney, J. S., Marley, N. A., Laskin, A., Shutthanandan, V., Xie, Y., Brune, W., Lesher, R., Shirley, T., and Jimenez, J. L.: Characterization of ambient aerosols in Mexico City during the MCMA-2003 campaign with Aerosol Mass Spectrometry: results from the CENICA Supersite,
Atmos. Chem. Phys., 6, 925-946, doi:10.5194/acp-6-925-2006, 2006.

Seinfeld, J. H. and Pandis, S. N.: Atmospheric Chemistry and Physics: From Air Pollution to Climate Change, 2nd Edn., John Wiley \& Sons, New York, 1232 pp., 2006.

Setyan, A., Zhang, Q., Merkel, M., Knighton, W. B., Sun, Y., Song, C., Shilling, J. E., Onasch, T. B., Herndon, S. C., Worsnop, D. R., Fast, J. D., Zaveri, R. A., Berg, L. K., Wiedensohler, A., Flowers, B. A., Dubey, M. K., and Subramanian, R.: Characterization of submicron particles influenced by mixed biogenic and anthropogenic emissions using high-resolution aerosol mass spectrometry: results from CARES, Atmos. Chem. Phys., 12, 8131-8156, doi:10.5194/acp-12-8131-2012, 2012.

Simoneit, B. R. T., Rushdi, A. I., bin Abas, M. R., and Didyk, B. M.: Alkyl Amides and Nitriles as Novel Tracers for Biomass Burning, Environ. Sci. Technol., 37, 16-21, doi:10.1021/es020811y, 2003.

Sun, J., Zhang, Q., Canagaratna, M. R., Zhang, Y., Ng, N. L., Sun, Y., Jayne, J. T., Zhang, X., Zhang, X., and Worsnop, D. R.: Highly time- and size-resolved characterization of submicron aerosol particles in Beijing using an Aerodyne Aerosol Mass Spectrometer, Atmos. Environ., 44, 131-140, doi:10.1016/j.atmosenv.2009.03.020, 2010.

Sun, Y., Zhang, Q., Macdonald, A. M., Hayden, K., Li, S. M., Liggio, J., Liu, P. S. K., Anlauf, K. G., Leaitch, W. R., Steffen, A., Cubison, M., Worsnop, D. R., van Donkelaar, A., and Martin, R. V.: Size-resolved aerosol chemistry on Whistler Mountain, Canada with a high-resolution aerosol mass spectrometer during INTEX-B, Atmos. Chem. Phys., 9, 3095-3111, doi:10.5194/acp9-3095-2009, 2009.

Sun, Y., Wang, Z., Dong, H., Yang, T., Li, J., Pan, X., Chen, P., and Jayne, J. T.: Characterization of summer organic and inorganic aerosols in Beijing, China with an Aerosol Chemical Speciation Monitor, Atmos. Environ., 51, 250-259, doi:10.1016/j.atmosenv.2012.01.013, 2012.

Sun, Y., Jiang, Q., Wang, Z., Fu, P., Li, J., Yang, T., and Yin, Y.: Investigation of the sources and evolution processes of severe haze pollution in Beijing in January 2013, J. Geophys. Res.-Atmos., 119, 4380-4398, doi:10.1002/2014jd021641, 2014.

Sun, Y. L., Zhang, Q., Schwab, J. J., Chen, W. N., Bae, M. S., Lin, Y. C., Hung, H. M., and Demerjian, K. L.: A case study of aerosol processing and evolution in summer in New York City, Atmos. Chem. Phys., 11, 12737-12750, doi:10.5194/acp11-12737-2011, 2011a.

Sun, Y.-L., Zhang, Q., Schwab, J. J., Demerjian, K. L., Chen, W.N., Bae, M.-S., Hung, H.-M., Hogrefe, O., Frank, B., Rattigan, O. V., and Lin, Y.-C.: Characterization of the sources and processes of organic and inorganic aerosols in New York city with a high-resolution time-of-flight aerosol mass apectrometer, Atmos. Chem. Phys., 11, 1581-1602, doi:10.5194/acp-11-15812011, 2011 b.

Ulbrich, I. M., Canagaratna, M. R., Zhang, Q., Worsnop, D. R., and Jimenez, J. L.: Interpretation of organic components from Positive Matrix Factorization of aerosol mass spectrometric data, Atmos. Chem. Phys., 9, 2891-2918, doi:10.5194/acp-9-2891-2009, 2009.

Wang, J., Ge, X., Chen, Y., Shen, Y., Zhang, Q., Sun, Y., Xu, J., Ge, S., Yu, H., and Chen, M.: Highly time-resolved urban aerosol characteristics during springtime in Yangtze River Delta, 
China: insights from soot particle aerosol mass spectrometry, Atmos. Chem. Phys., 16, 9109-9127, doi:10.5194/acp-16-91092016, 2016.

Weimer, S., Drewnick, F., Hogrefe, O., Schwab, J. J., Rhoads, K., Orsini, D., Canagaratna, M., Worsnop, D. R., and Demerjian, K. L.: Size-selective nonrefractory ambient aerosol measurements during the Particulate Matter Technology Assessment and Characterization Study - New York 2004 Winter Intensive in New York City, J. Geophys. Res., 111, D18305, doi:10.1029/2006JD007215, 2006.

Woody, M. C., Baker, K. R., Hayes, P. L., Jimenez, J. L., Koo, B., and Pye, H. O. T.: Understanding sources of organic aerosol during CalNex-2010 using the CMAQ-VBS, Atmos. Chem. Phys., 16, 4081-4100, doi:10.5194/acp-16-4081-2016, 2016.

Xu, J., Zhang, Q., Chen, M., Ge, X., Ren, J., and Qin, D.: Chemical composition, sources, and processes of urban aerosols during summertime in northwest China: insights from high-resolution aerosol mass spectrometry, Atmos. Chem. Phys., 14, 12593 12611, doi:10.5194/acp-14-12593-2014, 2014.

Xu, J., Shi, J., Zhang, Q., Ge, X., Canonaco, F., Prévôt, A. S. H., Vonwiller, M., Szidat, S., Ge, J., Ma, J., An, Y., Kang, S., and Qin, D.: Wintertime organic and inorganic aerosols in Lanzhou, China: sources, processes, and comparison with the results during summer, Atmos. Chem. Phys., 16, 14937-14957, doi:10.5194/acp-16-14937-2016, 2016.

Xu, L., Guo, H., Boyd, C. M., Klein, M., Bougiatioti, A., Cerully, K. M., Hite, J. R., Isaacman-VanWertz, G., Kreisberg, N. M., Knote, C., Olson, K., Koss, A., Goldstein, A. H., Hering, S. V., de Gouw, J., Baumann, K., Lee, S.-H., Nenes, A., Weber, R. J., and $\mathrm{Ng}$, N. L.: Effects of anthropogenic emissions on aerosol formation from isoprene and monoterpenes in the southeastern United States, P. Natl. Acad. Sci. USA, 112, 37-42, doi:10.1073/pnas.1417609112, 2015.

Young, D. E., Allan, J. D., Williams, P. I., Green, D. C., Flynn, M. J., Harrison, R. M., Yin, J., Gallagher, M. W., and Coe, H.: Investigating the annual behaviour of submicron secondary inorganic and organic aerosols in London, Atmos. Chem. Phys., 15, 6351-6366, doi:10.5194/acp-15-6351-2015, 2015.

Young, D. E., Kim, H., Parworth, C., Zhou, S., Zhang, X., Cappa, C. D., Seco, R., Kim, S., and Zhang, Q.: Influences of emission sources and meteorology on aerosol chemistry in a polluted urban environment: results from DISCOVER-AQ California, Atmos. Chem. Phys., 16, 5427-5451, doi:10.5194/acp-16-54272016, 2016.

Zhang, J. K., Sun, Y., Liu, Z. R., Ji, D. S., Hu, B., Liu, Q., and Wang, Y. S.: Characterization of submicron aerosols during a month of serious pollution in Beijing, 2013, Atmos. Chem. Phys., 14, 2887-2903, doi:10.5194/acp-14-2887-2014, 2014.

Zhang, Q., Alfarra, M. R., Worsnop, D. R., Allan, J. D., Coe, H., Canagaratna, M. R., and Jimenez, J. L.: Deconvolution and quantification of hydrocarbon-like and oxygenated organic aerosols based on aerosol mass spectrometry, Environ. Sci. Technol., 39, 4938-4952, doi:10.1021/es0485681, 2005a.
Zhang, Q., Canagaratna, M. R., Jayne, J. T., Worsnop, D. R., and Jimenez, J. L.: Time- and size-resolved chemical composition of submicron particles in Pittsburgh: Implications for aerosol sources and processes, J. Geophys. Res., 110, D07S09, doi:10.1029/2004JD004649, 2005b.

Zhang, Q., Jimenez, J. L., Canagaratna, M. R., Allan, J. D., Coe, H., Ulbrich, I., Alfarra, M. R., Takami, A., Middlebrook, A. M., Sun, Y. L., Dzepina, K., Dunlea, E., Docherty, K., DeCarlo, P. F., Salcedo, D., Onasch, T., Jayne, J. T., Miyoshi, T., Shimono, A., Hatakeyama, S., Takegawa, N., Kondo, Y., Schneider, J., Drewnick, F., Borrmann, S., Weimer, S., Demerjian, K., Williams, P., Bower, K., Bahreini, R., Cottrell, L., Griffin, R. J., Rautiainen, J., Sun, J. Y., Zhang, Y. M., and Worsnop, D. R.: Ubiquity and dominance of oxygenated species in organic aerosols in anthropogenically-influenced Northern Hemisphere midlatitudes, Geophys. Res. Lett., 34, L13801, doi:10.1029/2007gl029979, 2007a.

Zhang, Q., Jimenez, J. L., Worsnop, D. R., and Canagaratna, M.: A case study of urban particle acidity and its influence on secondary organic aerosol, Environ. Sci. Technol., 41, 3213-3219, doi:10.1021/Es061812j, 2007b.

Zhang, Q., Jimenez, J. L., Canagaratna, M. R., Ulbrich, I. M., Ng, N. L., Worsnop, D. R., and Sun, Y.: Understanding atmospheric organic aerosols via factor analysis of aerosol mass spectrometry: a review, Anal. Bioanal. Chem., 401, 3045-3067, doi:10.1007/s00216-011-5355-y, 2011.

Zhang, Y. J., Tang, L. L., Wang, Z., Yu, H. X., Sun, Y. L., Liu, D., Qin, W., Canonaco, F., Prévôt, A. S. H., Zhang, H. L., and Zhou, H. C.: Insights into characteristics, sources, and evolution of submicron aerosols during harvest seasons in the Yangtze River delta region, China, Atmos. Chem. Phys., 15, 1331-1349, doi:10.5194/acp-15-1331-2015, 2015.

Zhao, Y., Hu, M., Slanina, S., and Zhang, Y.: Chemical compositions of fine particulate organic matter emitted from Chinese cooking, Environ. Sci. Technol., 41, 99-105, doi:10.1021/es0614518, 2007.

Zhou, S., Collier, S., Jaffe, D. A., Briggs, N. L., Hee, J., Sedlacek III, A. J., Kleinman, L., Onasch, T. B., and Zhang, Q.: Regional Influence of Wildfires on Aerosol Chemistry in the Western US and Insights into Atmospheric Aging of Biomass Burning Organic Aerosol, Atmos. Chem. Phys. Discuss., doi:10.5194/acp-2016-823, in review, 2016a.

Zhou, S., Collier, S., Xu, J. Z., Mei, F., Wang, J., Lee, Y. N., Sedlacek III, A. J., Springston, S. R., Sun, Y. L., and Zhang, Q.: Influences of upwind emission sources and atmospheric processing on aerosol chemistry and properties at a rural location in the Northeastern U.S., J. Geophys. Res.-Atmos., 121, 6049-6065, doi:10.1002/2015jd024568, 2016b. 